\title{
Phytochemistry and pharmacological activity of the genus artemisia
}

\author{
Dheeraj Bisht ${ }^{1}$ Deepak Kumar ${ }^{2}$. \\ Dharmendra Kumar ${ }^{3,4} \cdot$ Kamal Dua $^{2,5}$. \\ Dinesh Kumar Chellappan ${ }^{6}$
}

Received: 1 July 2020 / Accepted: 26 March 2021 / Published online: 24 April 2021

(C) The Pharmaceutical Society of Korea 2021

\begin{abstract}
Artemisia and its allied species have been employed for conventional medicine in the Northern temperate regions of North America, Europe, and Asia for the treatments of digestive problems, morning sickness, irregular menstrual cycle, typhoid, epilepsy, renal problems, bronchitis malaria, etc. The multidisciplinary use of artemisia species has various other health benefits that are related to its traditional and modern pharmaceutical perspectives. The main objective of this review is to evaluate the traditional, modern, biological as well as pharmacological use of the essential oil and herbal extracts of Artemisia nilagirica, Artemisia parviflora, and other allied species of Artemisia. It also discusses the botanical circulation and its phytochemical constituents viz disaccharides, polysaccharides, glycosides, saponins, terpenoids, flavonoids, and carotenoids. The plants have different biological importance like antiparasitic, antimalarial, antihyperlipidemic, antiasthmatic,
\end{abstract}

Dheeraj Bisht

dheeraj.bisht729@gmail.com

1 Department of Pharmaceutical Sciences, Sir J. C. Bose Technical Campus Bhimtal, Kumaun University, Nainital, Uttarakhand 263136, India

2 School of Pharmaceutical Sciences, Shoolini University, Solan, H.P. 173 229, India

3 Department of Pharmaceutical Chemistry, Faculty of Pharmaceutical Sciences, UCSI University, 56000 Kuala Lumpur, Malaysia

4 Laureate Institute of Pharmacy, Distt. Kangra, Kathog, H.P. 176031, India

5 Discipline of Pharmacy, Graduate School of Health, University of Technology, Sydney 2007, Australia

6 Department of Life Sciences, School of Pharmacy, International Medical University (IMU), Bukit Jalil, 57000 Kuala Lumpur, Malaysia antiepileptic, antitubercular, antihypertensive, antidiabetic, anxiolytic, antiemetic, antidepressant, anticancer, hepatoprotective, gastroprotective, insecticidal, antiviral activities, and also against COVID-19. Toxicological studies showed that the plants at a low dose and short duration are non or lowtoxic. In contrast, a high dose at $3 \mathrm{~g} / \mathrm{kg}$ and for a longer duration can cause toxicity like rapid respiration, neurotoxicity, reproductive toxicity, etc. However, further in-depth studies are needed to determine the medicinal uses, clinical efficacy and safety are crucial next steps.

Keywords Artemisia - Phytochemical constituents . Essential oil · Sesquiterpenes - Pharmacological activity · COVID-19 $\cdot$ Toxicological studies

\section{Introduction}

The genus Artemisia belongs to the family Asteraceae, which is one of the most prominent disseminated genera comprising of 500 diverse kinds found in Northern temperate regions of North America, Europe, and Asia (Bora and Sharma 2011). The generic name 'Artemisia' is derived from 'Artemis,' which means Diana, a Greek Goddess. Artemisia vulgaris, L. was employed as an essential remedy for women's sickness in folk medicament. The genus has been certified for its remedial, curative, and therapeutic medicinal virtues, employed to synthesize essential oil used in medicine, food commodities, and cosmetics (Teixeira 2004; Verma et al. 2006; Ahuja et al. 2011, 2018; Pal and Ghosh 2018). Artemisia nilagirica regionally designated as "Indian wormwood" pertains to the Asteraceae family (Suresh et al. 2011). It is popularly known as nagdona, which propagates up to $150 \mathrm{~cm}$ on nitrogenous soil in mountainous districts of India (Joshi et al. 2016). The leaves are 
5-20 cm in height, peachy, soft, dark green on apex pale green with tiny white hairs on base. It is the medicinal plant that has been described to be pre-owned over ten decades employed to treat a large number of ailments; their signs and symptoms like inflammation, diabetes, malaria, anxiety, depression and several other microbial illnesses (Mohanty et al. 2018). The plant has exploited to possess several biochemical constituents i.e., volatile oils and essential oil that is considered for the cure of diverse kinds of ailments and disabilities (Kishore et al. 2001; Singh et al. 2015; Mishra et al. 2017). It contains a sesquiterpene lactone and flavonoids used as antimicrobial, insecticidal, along with anticancer activities, also applicable to cure neurological problems, dermal infections, inflammation, and to treat epileptic disorders (Banerji et al. 1990; Shinde et al. 2016). A. nilagirica has confirmed to have ayurvedic as well as homeopathic remedial properties (Uniyal et al. 1985). The juice of leaflets of this plant has been used for the treatments of intestinal worms, threatened abortion, vomiting, and rheumatism (Badoni et al. 2010; Panda et al. 2018; Hijazi and Salhab 2010). Besides this, the genus artemisia species mentioned in traditional pharmacopeias of different ethnic groups. The numerous species like A. cappilaries, A. Sacrotum, A. absinthium, A. herba alba, A. annua, A. vulgaris, A. tridentata, A. argentea, A. ludoviciana, A. Mexicana, etc posssess impotrant therapeutic properties (Yamahara and Kobayashi 1989). Mugwort leaves and stems are used therapeutically as an acrid pungent assimilative tonic, uterine stimulant and antirheumatic (Balunas and Kinghorn 2005). Few species of the genus artemisia recommended for the treatment of gastrointestinal problems, hypertension (Zeb et al. 2018), also possess potent immunomodulatory, antihypertensive, anticancer, and anti-inflammatory properties (Lian et al. 2018; Mohanty et al. 2018). Mugwort contains secondary metabolites like flavonoids, terpenoids, saponins, and polysaccharides, etc. Arglabin is a sesquiterpene lactone found mostly in all species of Artemisia, exhibits noticeable anticancer effects against varying tumor cell lines (Adekenov et al. 1982). Artemisinin isolated from Artemisia annua known as "qinghaosu" is sesquiterpene lactone endoperoxide used for the prevention and cure of malaria and cancer. Several analogs such as artesunic acid, artelinic acid, arteether as well as artemether can be semi synthesized and are extremely proficient against malaria induced by multidrug-resistant Plasmodium falciparum (Jain et al. 2000; Abolaji et al. 2013). Artemisinin is present in leaves and flowers of the plant at a minimal amount; its dehydrated weight renders from 0.01 to $0.8 \%$. Various procedures can be applied to increase the synthesis of artemisinin, hence, to yield it in an excess concentration to make it readily and smoothly approachable for the benefit of mankind.

In this review, we have focused on the chemical constituents, traditional uses, diverse pharmacological importance of A. nilagirica, A. parviflora, and some other allied species of genus artemisia, and our previously published article on different valuable medicinal plants (Sharma et al. 2019) encourages us to write this article. The valuable pieces of information provided in this review will help the researcher to design a safe formulation for the cure of different ailments.

\section{Traditional uses of Artemisia nilagirica}

Artemisia nilagirica plant is traditionally used for the cure of illness such as digestive problems, morning sickness, irregular menstrual cycle, typhoid, epilepsy, renal problems, bronchitis, and malaria, etc. (Suresh et al. 2011). The extracts of A. nilagirica proves an extensive range of antibacterial effects on the assessed microorganisms. It has also practiced to diminishing as well as restrain the pangs of childbirth, systematize women's menstrual irregularities, also be used as an abortifacient (Tahir et al. 2015). A. nilagirica was proclaimed for efficient nematicidal activity against Meloidogyne incognita that is a plant-parasitic roundworm (Kalaiselvi et al. 2019).

\section{Chemical constituents of Artemisia nilagirica}

The phytochemical assessment of A. nilagirica showed the presence of different phytoconstituents namely tannins, alkaloids, flavonoids, terpenoids, amino acids, glycosides, and quinines, etc. (Arokiyaraj et al. 2012; Rani et al. 2012). Numerous secondary metabolites like terpenoids, flavonoids, polysaccharides as well as saponins have been characterized as well as authenticated by using High-performance liquid chromatography (HPLC), Gas Chromatography-Mass Spectroscopy (GC-MS), and Nuclear Magnetic Resonance (NMR) (Xie et al. 2008; Avula et al. 2009).

\section{Artemisa parviflora}

Artemisia parviflora Buch is a non-aromatic, erect and tall perennial herb with versatile sessile, linear cuneate leaves, greenish-white flower heads in racemes (Rana et al. 2003). Leaves are linear-oblong much reduced terminally, panicles are terminating in the branchlets. Capitulum is creamcolored. Glabrous phyllaries and sterile disc florets are present.

\section{Traditional uses of Artemisia parviflora}

This plant has been traditionally employed as an appetizer, antiviral, diuretic, wound healer, anti-inflammatory, 
antioxidant, and antifebrile medicine, for treatment of sores, injury, wounds, leprosy, cough, asthma, and vaginitis (Suresh et al. 2010; Ahameethunisa and Hopper 2012; Koul et al. 2017; Malik 2017). It is also reported as a fodder plant of Uttarakhand, India (Singh et al. 2008), an entire plant can be utilized to mitigate fever (antipyretic) (Bhat et al. 2013). It is also associated with the ethnoveterinary drug as an anthelmintic agent (Gupta et al. 2010). A decoction formulation of the leaves buds of the plant can be consumed with stock animals and can be applied for the treatment of roundworm infections (Kumari et al. 2009). It is frequently availed as a traditional European nostrum for the cure of amenorrhea, dysmenorrhea, and also employed as a choleretic agent (Aziz et al. 2018).

\section{Chemical constituents of Artemisia parviflora}

The essential oil obtained through aerial regions of $A$. parviflora from Pauri Garhwal (Uttarakhand, India) was commenced to perceive $\beta$-caryophyllene (15.3\%), camphor (11.4\%), germacrene D (14.7\%), artemisia ketone (7.8\%), 1,8-cineole (5.8\%) (Haider et al. 2010; Tewari et al. 2015). The chemical constituents of A. parviflora Buch have been examined through Gas chromatography (GC), Gas chromatography-Mass spectroscopy (GC-MS) (Rana et al. 2003). Twenty-two chemical constituents isolated from $A$. parviflora accounts for more than $72 \%$ of the oil obtained, (Brenda et al. 2007). The medicinally active constituents were $\beta$-caryophyllene (15.3\%), germacrene-D (14.7\%), camphor (11.4\%), ketone derivatives (7.8\%), 1,8 cineole (5.8\%), $\alpha$-copaene (2.6\%), alcohol derivatives (2.6\%), terpene-4-ol $(2.3 \%)$, caryophyllene oxide $(1.2 \%), \alpha$-pinene $(1.1 \%)$, sabinyl acetate $(1.1 \%), \alpha$-humulene $(1.1 \%)$. The plant also possesses sesquiterpenes and coumarin such as articanin, flavone-jacosidin, and scopoletin. (Pandey and Singh 2017; Paramakrishnan et al. 2012). In consideration of Suresh et al. (2012), it was suggested that phytochemical compositions of
A. parviflora Roxb were reported to be flavonoids, tannins, coumarins, phenols, alkaloids sterols/terpenoids, germacrene D (Brown 2010; Amirmohammadi et al. 2014; Salehi et al. 2018; Goel et al. 2019).

\section{Chemical constituents of genus artemisia species}

Constitutional analysis of the composition of medicinal constituents of genus artemisia stated that a notable alteration in the concentration of chemical constituents is due to seasonal and atmospheric adjustments (Costa et al. 2009; Padalia et al. 2014). The genus artemisia possesses numerous therapeutic components, some important medicinally active constituents of this genus are mentioned in following Table 1 (Rashmi et al. 2014; Stappen et al. 2014; Sonker et al. 2015; Farahani et al. 2017; Hussain et al. 2017).

The various non-volatile, volatile, flavonoids, phenolic acids, coumarin derivatives, monoterpene, and sesquiterpene constituents of Artemisia species were informed (Wallaart et al. 1999; Aberham et al. 2010; Khan et al. 2016; Ahuja et al. 2018; Nigam et al. 2019) given in the Fig. 1 compound 1-16, Fig. 2 compound 17-31, and Fig. 3 compound 32-87 respectively.

\section{Pharmacological studies; uses in traditional medicines of genus artemisia}

Infusions of leaves are employed as hemostatic to extenuate the burning sensation in conjunctivitis. The herb is also considered as an emmenagogue, anthelmintic and stomachic (Irum et al. 2017). The roots of grass acclimated as a tonic as well as an antiseptic. This medicinal herb also manifests other important therapeutic activities like antimicrobial, antiulcer, anticancer, antioxidant, asthmatic insecticidal, larvicidal, and anti-inflammatory ( $\mathrm{Ng} 2004$;
Table 1 Chemical compositions of some medicinally active constituents of genus artemisia essential oils

\begin{tabular}{lclc}
\hline Compound & Relative content & Compound & Relative content \\
\hline$\beta$-Myrcene & 0.2 & $\alpha$-Phellrene & 2.1 \\
$\beta$-Pinene & 0.9 & Pinocarvone & 3.7 \\
$\alpha$-Humulene & 0.3 & $(Z)$-Citral & 2.1 \\
$\alpha$-Pinene & 1.1 & Sabinene & 14.3 \\
$\gamma$-Terpinene & 0.3 & Germacrene D & 2.1 \\
Caryophyllene & 1.3 & Camphor & 22.8 \\
Curcumene & 0.4 & Eucalyptol & 2.3 \\
Caryophyllene oxide & 0.6 & Camphene & 2.7 \\
DL-Limonene & 1.1 & $\alpha$-Thujone & 14.6 \\
$(E)$-Citral & 1.1 & trans-Caryophyllene & 16.7 \\
Total identified & 91.1 & & \\
\hline
\end{tabular}


Fig. 1 Some non-volatile constituents of Artemisia species

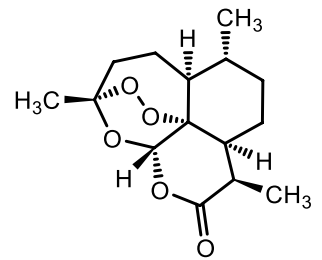

Artemisinin (1)<smiles>C=C1C(=O)O[C@@]23[C@H](C)CC[C@@]2(C)[C@@H](C)CC[C@H]13</smiles>

Arteanniun B (2)<smiles>O=C(O)/C=C/c1ccc(O)c(O)c1</smiles>

Caffeic Acid (3)<smiles>COc1cc(/C=C/C(=O)O)ccc1O</smiles>

Ferulic acid (4)<smiles>O=C(O)/C=C/c1ccccc1</smiles>

Cinnamic acid (5)<smiles>O=C(O)/C=C/c1ccc(O)cc1</smiles>

$p$-coumaric acid (6)<smiles>O=C(O)c1ccc(O)cc1</smiles>

$p$-hydroxybenzoic acid (7)<smiles>O=C(/C=C/c1ccc(O)c(O)c1)OC1C[C@](O)(C(=O)O)C[C@H](O)[C@H]1O</smiles>

Chlorogenic acid (11)<smiles>COc1cc(C(=O)O)ccc1O</smiles>

Vanillic acid (8)<smiles>O=C(O)c1cc(O)c(O)c(O)c1</smiles>

Gallic acid (9)<smiles>COc1cc(C(=O)O)cc(OC)c1O</smiles>

Syringic acid (10)

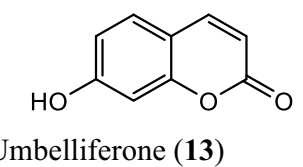<smiles>COc1cc2ccc(=O)oc2cc1O</smiles>

Neochlorogenic acid (12)<smiles>COc1cc(O)c2c(=O)cc(-c3ccc(O)cc3)oc2c1</smiles>

Genkwanin (15)<smiles>COc1cc(O)c2c(=O)c(O)c(-c3ccc(O)c(O)c3)oc2c1</smiles>

Rhamnetin (16) 
Fig. 2 Some volatile constituents of Artemisia species<smiles>CC(C)=CCCC(C)=CCO</smiles><smiles>C=CC(=C)CCC=C(C)C</smiles>

Geraniol (17)

$\beta$-myrcene (18)<smiles>C=C[C@](C)(O)CCC=C(C)C</smiles><smiles>CC1=CCC(C(C)C)=CC1</smiles>

(-)-linalool (20) $\alpha$-terpinene (21) $\gamma$-terpinene (22)<smiles>C=C(C)C1CC=C(C)CC1</smiles>

Limonene (19)

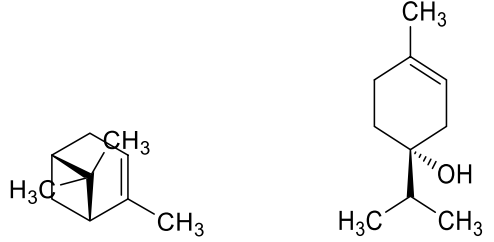

$\alpha$-pinene (23) Terpinen-4-ol (24)<smiles>CC12CCC(CC1=O)C2(C)C</smiles><smiles>C=C1C2CCC(C2)C1(C)C</smiles>

Camphor (25)<smiles>CC1=CC(=O)C(C(C)C)CC1</smiles>

Piperitone (28)

Camphene (26)<smiles>CC(C)C12CC(=O)C(C1)C2C</smiles>

Thujone (29)
Ahameethunisa and Hopper 2010; Paneerselvam et al. 2012; Naik et al. 2014; Balasubramani et al. 2018).

The various bacterial races, namely Salmonella, Pseudomonas, Staphylococcus may induce several kinds of ailments. Pseudomonas aeruginosa accounts for respiratory tract contamination, toxemia in patients suffering from cystic fibrosis and annihilation of the immune organization (Esen et al. 2001; Rahimi et al. 2011).

\section{Therapeutic uses of artemisia and its allied species}

The mugwort plant showed several therapeutic applications in folk medicine that involves gastrointestinal tract like ulcer indigestion and hepatic problems (Gilani et al. 2005; Gruenwald et al. 2008; Nadeem et al. 2013). The plant is also applied in the treatment of worm infection, epilepsy, anxiety, insomnia, autonomic neurosis, general irritability, and neurasthenia, etc. It is not used during breastfeeding (Gruenwald et al. 2008; Gupta et al. 2014). The essential oil of the plant is considered to have a variety of pharmacological actions, with an extended spectrum of bioactivity, due to the presence of multiple functioning metabolites of the subsidiary chemical constituents, which promote their operation through a different mode of action (Walter and Memory 2003; Silva 2004). It also proved to be a pain killer in conjunction with acupuncture treatment, and in China, it is often employed for moxibustion (Yoshikawa et al. 1996). A powder leaves or paste is used for skin problems and also implicated as a poor alternative for cinchona for reducing the episodes of malaria fever (Haider et al. 2003; Judzentiene and Buzelyte 2006).

\section{Utility benefits of Artemisia species in food technology}

At present, there has been an increasing demand regarding the feasible utilization of medicinal plants in their natural 
<smiles>C=CC(C=C(C)C)C(C)(C)O</smiles>

Santolina alcohol (32)<smiles>[M]C(C1(C)CCC(C)(C=C)O1)C1(O)C[C@H](C(C)C)OO1</smiles>

Sesquiterpene proxy hemiketal (34)<smiles>C=CC(C)(C)C(=O)C=C(C)C</smiles>

Artemisia ketone (33)

Borneol (35)<smiles>C=C1CCC=C(C)CC[C@@H]2C(C)C[C@H]1C2C</smiles><smiles>Cc1ccc(C(C)C)cc1</smiles>

Caryophyllene (36)

p-Cymene (37)<smiles>CC1=CC[C@@H](C(C)C)C=C1</smiles>

$\alpha$-Phellandrene (38)<smiles>CC1=CCC2C(=O)C1C2(C)C</smiles>

Chrysanthenone (39)<smiles>C=C[C@]1(C)CC[C@H](C(C)C(=O)CC=C(C)C)C1</smiles>

Davanone (40)<smiles>O=c1cc(-c2ccccc2)oc2cc(O)cc(O)c12</smiles>

Chrysin (41)<smiles>O=c1cc(-c2ccc(O)cc2)oc2cc(O)cc(O)c12</smiles>

Apigenin (42)<smiles>O=c1cc(-c2ccc(O)c(O)c2)oc2cc(O)cc(O)c12</smiles>

Luteolin (43)

Fig. 3 Some chemical constituents of genus artemisia i.e. flavonoids, phenolic acids, coumarin derivatives, monoterpene, and sesquiterpene

forms for pest control in the agriculture field which is less hazardous to the surroundings as well as for human health (Wang et al. 2006; Hussain et al. 2008). The essential oil of mugwort has been suggested to decrease or suppress the development of several kinds of insects, microbial parasites, and might be applied to insulate foods from spoilage. 
<smiles></smiles>

6-Hydroxy luteolin (44)

Kaemferol (45)

Quercetin (46)<smiles></smiles>

Myrcetin (47)

Eriodictyol (48)

Rhamnetin (49)<smiles>COc1cc(-c2oc3cc(O)cc(O)c3c(=O)c2O)ccc1O</smiles>

Isorhamnetin (50)

Eupatilin (51)<smiles>COc1cc(O)c2c(c1)O[C@@H](c1ccc(O)cc1)CC2=O</smiles>

Sakuranetin (52)<smiles>O=C1CC(c2ccccc2)Oc2cc(O)cc(O)c21</smiles>

Pinocembrin (53)<smiles>C[C@H]1O[C@H](Oc2c(-c3ccc(O)cc3)oc3cc(O)cc(O)c3c2=O)[C@H](O)[C@@H](O)[C@@H]1O</smiles>

Kaempferol-3-O- rhamnoside (54)<smiles>COc1cc(-c2cc(=O)c3c(O)c(OC)c(O)cc3o2)ccc1O</smiles>

Jaceosidin (55)

Fig. 3 (continued) 
<smiles>O=c1c(O[C@@H]2O[C@H](CO)[C@@H](O)[C@H](O)[C@H]2O)c(-c2ccc(O)c(O)c2)oc2cc(O)cc(O)c12</smiles>

Hyperoside (56)<smiles>COc1ccc([C@H]2CC(=O)c3c(O)cc(O[C@@H]4O[C@H](CO[C@@H]5O[C@@H](C)[C@H](O)[C@H](O)[C@H]5O)[C@@H](O)[C@H](O)[C@H]4O)cc3O2)cc1O</smiles>

Hesperidin (57)<smiles>C[C@H]1O[C@H](OC[C@H]2O[C@H](Oc3c(-c4ccc(O)c(O)c4)oc4cc(O)cc(O)c4c3=O)[C@@H](O)[C@H](O)[C@H]2O)[C@H](O)[C@@H](O)[C@@H]1O</smiles>

Rutin (58)<smiles>COc1ccc(/C=C/C(=O)O)cc1</smiles>

4-methoxycinnnmaic acid(59)<smiles>COc1cc(/C=C/C(=O)O)ccc1O</smiles><smiles>O=c1ccc2cc(O)c(O)cc2o1</smiles>

Chlorogenic acid (60) trans-ferulic acid (61) Esculetin (62)

Fig. 3 (continued) 
<smiles>CC1=CC(=O)C(C(C)C)CC1</smiles>

Piperitone (63)<smiles>C=C1CC[C@@H]2[C@H](C2(C)C)[C@]2(C)[C@H]1CCC2(C)O</smiles>

Spathulenol (66)<smiles>CO[C@H]1O[C@H]2O[C@]3(C)CC[C@@H]4[C@H](C)CC[C@@H]([C@H]1C)[C@@]24OO3</smiles>

Artemether (68)

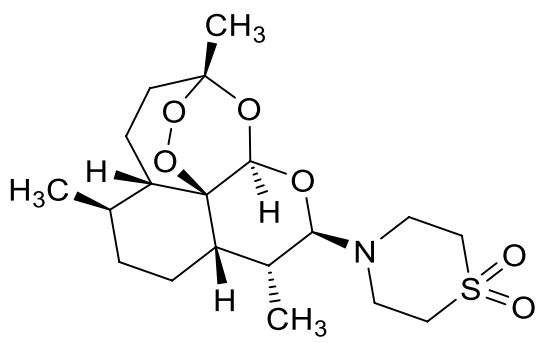

Artemisone (70)<smiles>C=C(C(=O)O)[C@H]1CC[C@@H](C)[C@H]2CCC(C)=C[C@H]12</smiles>

Artemisinic acid (72)<smiles>C=C1/C=C/C(C(C)C)CC/C=C(/C)CC1</smiles>

Germacrene D (64)<smiles>C=CC1(C)CCC(C(=C)C)CC1C(=C)C</smiles>

$\beta$-elemene (67)

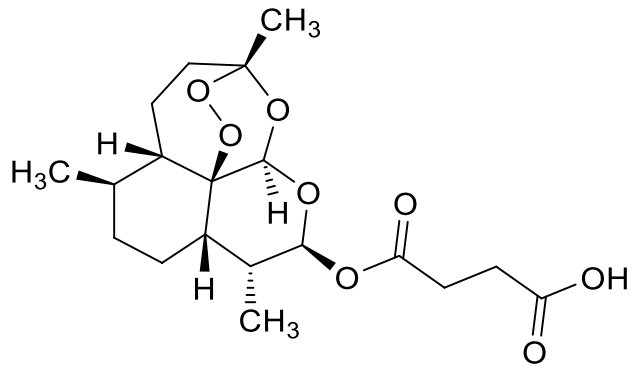

Artesunic Acid (69)

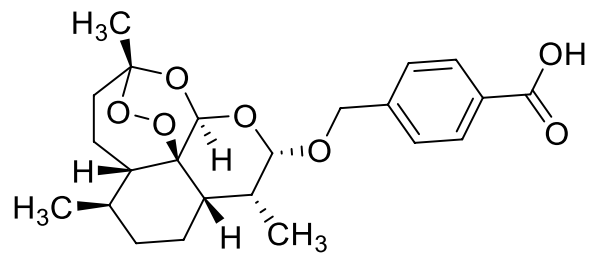

Artelinic acid (71)

Arglabin (65)<smiles>C[C@@H]1CC[C@H]2[C@@H](C)C(O)O[C@H]3O[C@]4(C)CC[C@@H]1[C@@]32OO4</smiles><smiles>C=C1C(=O)C[C@H]2CCC(C)(C)CC[C@@H]12</smiles>

\section{)}




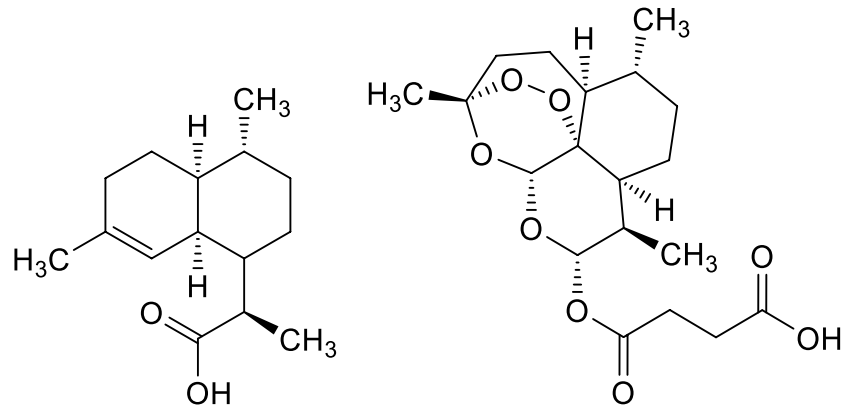

Dihydroartemisinic acid (74)<smiles>C=C1C(=O)O[C@]23C[C@@](C)(O)CC[C@H]2C(C)CC[C@H]13</smiles>

Arteanniun B (77)<smiles>CCO[C@H]1O[C@@H]2O[C@]3(C)CC[C@@H]4[C@H](C)CC[C@@H]([C@H]1C)[C@@]24OO3</smiles>

Arteether (76)<smiles>COc1ccc(-c2oc3cc(OC)c(OC)c(O)c3c(=O)c2OC)cc1O</smiles>

Casticin (79)<smiles>COc1cc(O)c2c(c1)OC(c1ccc(O)cc1)C(O)C2=O</smiles>

7-methoxyaromadendrin (81)<smiles>C[C@H]1CC[C@]2(C(=O)O)CC[C@]3(C)C(=CC[C@H]4[C@@]3(C)CC[C@]3(C)C(C)(C)[C@@H](O)CC[C@]43C)[C@H]2[C@@H]1C</smiles>

Ursolic acid (83)<smiles>COc1cc(O)c2c(c1)OC(c1ccc(O)cc1)CC2=O</smiles>

Sakuranetin (80)<smiles></smiles>

Carnosol (82)

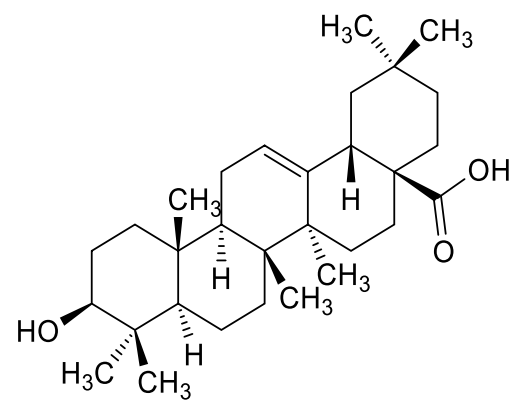

Oleanolic acid (84)

Fig. 3 (continued) 
<smiles>COc1cc([C@H]2OC[C@@H]3[C@H]2CO[C@H]3c2cc(OC)c(OC)c(OC)c2)cc(OC)c1OC</smiles>

Epiyangambin (85)<smiles>CC1=CCCC2[C@H](C)C(=O)O[C@@H]2C1</smiles>

Ketopelenolide B (87)

Fig. 3 (continued)

Mugwort essential oil exhibits fumigant repellent activity against different microbial strains involving Staphylococcus aureus, Salmonella typhimurium, Cida albicans, Escherichia coli, Staphylococcus epidermidis, Enterococcus faecalis, and Enterobacter cloacae applying disc diffusion technique collated with the positive control (ketoconazole, ceftazidime). The essential oil can develop a zone of inhibition larger than the standard drug, therefore, recommending its utilization as an antimicrobial compound. The potent antimicrobial property of mugwort essential oil is due to 1,8-cineole, camphene, and $\alpha$-thujone, whereas the antineoplastic property is because of artemisinin (Sun et al. 1992; Blagojevic et al. 2006; Jasinskas et al. 2014).

It has been reported that mugwort incorporating natural supplements and possesses potent antioxidant activity (Juteau et al. 2002; Erel et al. 2012). It is prominently preferred that the extracts of phenolic flavonoids parts of the A. vulgaris have found efficient antioxidant activity (Wright 2002; Albayrak et al. 2010). The rich amount of flavonoid indicates an immense level of antioxidant activity (Matvieieva et al. 2019). It is also known that some flavonoid constituents are used in the treatment of neurodegenerative disorders, Alzheimer's disease (Pradeep and Rengaswamy 2016) and also manifest antihyperlipidemic effects (Dib and Alaouri-faris 2019). The important oil obtained from the stem part of mugwort has an influential larvicidal activity against Aedes aegypti when used in small concentration, therefore, scrutinized as a natural<smiles>COc1cc([C@@H]2OC[C@H]3[C@@H](c4cc(OC)c5c(c4)OCO5)OC[C@@H]32)cc(OC)c1OC</smiles>

Sesartemin (86) larvicidal compound against some carrier-mediated illness and for pest management in food technology (Govindaraj and Kumari 2013). Mugwort essential oil is also confirmed for its insecticidal effect for Tribolium castaneum (Herbst), Collosobruchus maculates (F.), and Rhyzopertha dominica (F.) (Tigno et al. 2000; Sharifian et al. 2013).

\section{Chemical compositions of mugwort (Artemisa vulgaris) essential oil}

The robust fragrance scent of A. nilagirica, A. vulgaris, and their species are principally due to the immense amount of volatile terpene and its active components of the essential oil (Abad et al. 2012). The chemical ingredients of A. vulgaris include flavonoids, coumarins, volatile oils, sesquiterpene, lactones, inulin, and traces of alkaloids. The major components of essential oils are camphene, 1,8 cineole, $\alpha$-thujone, germacrene $\mathrm{D}, \beta$ caryophyllene, and camphor (Jerkovic et al. 2003) are given in Table 2, and extraction of mugwort oil is represented in Table 3. 
Table 2 Phytochemical analysis of $A$. nilagirica extracts

\begin{tabular}{llllllll}
\hline S. no. & Test & Chloroform & Diethyl ether & Ethanol & Hexane & Methanol & $\begin{array}{l}\text { Petro- } \\
\text { leum } \\
\text { ether }\end{array}$ \\
\hline 1 & & & & & & & \\
2 & Phlobatannins & - & - & - & + & - & + \\
2 & Glycosides & - & - & - & - & - & - \\
3 & Flavonoids & ++ & + & ++ & ++ & ++ & + \\
4 & Saponins & - & - & + & - & + & - \\
5 & Amino acids & - & - & + & - & ++ & - \\
6 & Carbohydrates & - & - & - & - & + & - \\
7 & Alkaloids & ++ & ++ & ++ & ++ & ++ & + \\
8 & Volatile oils & - & - & - & + & + & - \\
9 & Phenol & ++ & + & ++ & + & ++ & + \\
10 & Tannins & - & + & ++ & - & ++ & - \\
11 & Terpenoids & ++ & ++ & ++ & ++ & ++ & ++ \\
12 & Quinines & + & + & + & + & + & + \\
13 & Hydrolysable tannins & - & - & - & - & - & - \\
\hline
\end{tabular}

$(-)$ = Absent, $(+)=$ Present,$(++)=$ Abundant

Table 3 Extraction of oil from asunder segments of mugwort (A. vulgaris)

\begin{tabular}{lllll}
\hline Origin/parts & Procedure & Equipment & Yield (\%) & References \\
\hline China/leaves stems & Hydrodistillation & Clevenger & - & Wang et al. (2006) \\
Sebia/aerial parts & Hydrodistillation & Clevenger & - & Blagojevic et al. (2006) \\
North Lithuania/ aerial parts & $\begin{array}{l}\text { Hydrodistillation with hexane } \\
\text { diethyl ether combination }\end{array}$ & - & Judzentiene and Buzelyte (2006) \\
& Hyrodistillation & Clevenger & 0.40 & Erel et al. (2012) \\
Turkey/aerial parts & Hydrodistillation & Likens-Nickerson & - & Mucciarelli et al. (1995) \\
Italy/aerial parts & apparatus & & Alizedah et al. (2012) \\
Iran/aerial parts & Steam distillation & Clevenger & 1.4 & Bhatt et al. (2007) \\
Nepal/leaves & Steam distillation & Clevenger & - & Pino et al. (1999) \\
Cuba/aerial parts & Hydrodistillation & Clevenger & 0.1 & Haider et al. (2003) \\
India/aerial parts & Hydrodistillation & Clevenger & $0.16-0.5$ & Thao et al. (2004) \\
Vietnam/aerial parts & Hydrodistillation & Clevenger & $0.32-1.14$ & Govindaraj and Kumari (2013) \\
India/stem & Hydrodistillation & Clevenger & - & Bamoniri et al. (2010) \\
Iran/aerial parts & Hydrodistillation & Clevenger & 0.25 & \\
\hline
\end{tabular}

\section{Pharmacological activities}

\section{Antioxidant activity}

Free radicals are those compounds that contain unpaired electrons, are extremely reactive species such as many reactive oxygen species (ROS) usually are the outcomes of routine cellular biotransformation in the biological systems (Qadir et al. 2014; Zhang et al. 2018). ROS is a complete range of large riposte molecules that are produced from oxygen metabolism (Dhanapal et al. 2016). Antioxidants maintain the equilibrium of radicals in cells, which prohibit oxidative stress against different ailments (Szerlauth et al. 2019). However, the excess formation of reactive oxygen species (ROS) is due to severance of the exquisite balance in the middle of the antioxidant system, its production is accountable for the oxidative damage which results in the deterioration of cellular macromolecules like enzymes, lipids, deoxyribose nucleic acids (DNA), and proteins (Halliwell and Gutteridges 1984; Msaada et al. 2015). This imbalance can be used for the diagnosis of numerous disorders like necrosis, swelling, Parkinson's disease, Alzheimer's sickness, high blood pressure, hyperglycemia, atherosclerosis, heart-related problems, and immunological perturbation (Morris et al. 2013; Wang et al. 2019). ROS can cause necrosis due to their strength to enlarge cell growth, endurance molecular wandering. Moreover, it can also responsible for DNA impairment, which evinces in the form of genetic 
complications that prompt tumorigenicity and ensuing tumor development (Storz 2005). Malignancy is one of the fatal diseases predominantly in public health aspects in both progressing as well as the progressed world (Prakash et al. 2013). In conjunction with this, current perspectives of cancer therapy, for example, immunosuppression, radiotherapy, chemotherapy and surgery, are integrated with a vast mortality rate despite substantial development in cancer therapy of cytostatic compounds (Sidaoui et al. 2016). Furthermore, the results of the presently available procedure for the diagnosis of several cancers are clear, mainly when cancer has attained the metastatic phase and cellular progression of cancer has been done (Seo et al. 2003; Mojarab et al. 2009).

Antioxidants afford a cellular protective mechanism against oxidative stress within the human body. They pertain to the potential to extinguish reactive oxygen species by furnishing hydrogen atoms or electrons, chelating transitional metal ions, invigoration of enzymes, namely superoxide dismutase (SOD), catalase (CAT) glutathione peroxidase (GPx) as well as preventing the oxidizing entities. However, these protective techniques are sometimes inadequate due to the large pathological condition; hence, antioxidant additives play an essential role in encountering oxidative detriment (Gul et al. 2013). Medicinal plants have rescued association in contemporary times due to their elevating abundant biological characteristics appearing apperception of their provenance, functioning structural variations (Sen and Samanta 2014). Medicinal plants are attaining significant consideration because of their remarkable antioxidant potential with lesser side effects (Auddy et al. 2003). They accommodate a vast range of chemical compositions, which may impart their effect specifically or corroboratory to cure the diseases integrated with oxidative stress, ameliorate health (Bhatt et al. 2007, 2013). The polyphenolic preparation of extract from leaves of $A$. апnиa, and A. absinthium L. was estimated as a modality of natural antioxidants (Skowyra et al. 2014). Leaves of $A$. апnиа, extract for antioxidant activity have been performed by interpolating different solvents, i.e., chloroform, hexane, ethyl acetate, methanol-water. The antioxidant potential is evaluated by estimating total phenolic and flavonoid content (TPC and TFC), ferric reducing antioxidant power (FRAP), Trolox equivalent antioxidant capacity (TEAC), 2,2-Diphenyl-2-picrylhydrazyl Hydrate (DPPH) radical scavenging activity, and lipid peroxidation. The extreme TPC, TFC, TEAC, DPPH radical scavenging, and little lipid peroxidation effects were carried out in methanol $\left(\mathrm{CH}_{3} \mathrm{OH}\right)$ extracts, although aqueous extract evinces exorbitant ferric reducing antioxidant strength demonstrating $\mathrm{CH}_{3} \mathrm{OH}$ to be the highly suited suitable extract (Temraz and El-tantawy 2008; Iqbal et al. 2012; Katiyar et al. 2012; Qadir et al. 2014; Pereira et al. 2018; Sembiring et al. 2018). The aqueous ethanolic extracts of A. nilagirica asserted for estimation of in-vitro antioxidant activity, superoxide scavenging activity, total flavanol content, total phenolic content, hydrogen donating activity and reducing power assay, etc. (Devmurari et al. 2010; Khezrilu and Heidari 2014; Pal and Ghosh 2018).

\section{Antimicrobial activity}

It has well established that the diethyl ether extract of the leaves of A. nilagirica demonstrated antimicrobial properties against the soil-borned plant pathogen i.e., Phytophthora capsici. The disc diffusion method has been applied to perform the antimicrobial activity. The results showed that the mycelial development of $P$. capsici entirely suppressed by a concentration of $100 \mathrm{ppm}$ of the oil in the carrot agar vehicle and shown in Table 4.

The inhibitory effect against $P$. capsici is due to the presence of thujones about $41.9 \%$. It has been illustrated that similar activity has been done by utilizing cedar leaf oil and A. nilagirica oil (Shafi et al. 2004). The plant extracts have shown extended activity against Pseudomonas aeruginosa, Staphylococcus typhi, Escherichia coli, Yersinia enterocolitica, Bacillus subtilis, Cida albicans, Staphylococcus aureus, and Proteus vulgaris. It has been reported that $P$. aeruginos $a$ exhibited the largest zone of inhibition at 16,17, $19 \mathrm{~mm}$ at 100,150-200 $\mu \mathrm{g}$ concentrations serially. B. subtilis, S. typhi displayed inhibition zones of 14,16 and $18 \mathrm{~mm}$, pursued by $S$. aureus with 13,15 , and $18 \mathrm{~mm}$ at three separate concentrations (100, 150 , and $200 \mu \mathrm{g})$. Escherichia coli showed the zone of inhibition (14, 15 and $17 \mathrm{~mm})$ at 100,150 and $200 \mu \mathrm{g}$, serially. The microbial characteristics of A. nilagirica were reported by numerous investigational groups; it possesses potent antibacterial activity towards Bacillus subtilis, Staphylococcus aureus, and Klebsiella pneumonia (Rao et al. 2006).

Table 4 Antimicrobial action of plant extracts from Artemisia nilagirica (Clarke) Pamp (Parameswari et al. 2019)

\begin{tabular}{llllll}
\hline Bacterial & \multicolumn{3}{l}{$\begin{array}{l}\text { The concentration of the } \\
\text { leaf extract }(\mu \mathrm{g})\end{array}$} & Standard \\
\cline { 2 - 5 } & 50 & 100 & 150 & 200 & \\
\hline Cida albicans & 3 & 6 & 8 & 10 & 12 \\
Staphylococcus aureus & 11 & 13 & 15 & 18 & 20 \\
Escherichia coli & 12 & 14 & 15 & 17 & 19 \\
Bacillus subtilis & 12 & 14 & 16 & 18 & 40 \\
Yersinia enterocolitica & - & - & - & - & 16 \\
Pseudomonas aeruginosa & 13 & 16 & 17 & 19 & 43 \\
Proteus vulgaris & - & - & - & - & 13 \\
Salmonella typhi & 12 & 14 & 16 & 18 & 33 \\
\hline
\end{tabular}




\section{Antifungal activity}

The in-vitro antifungal effect of essential oils of A. nilagirica along with Juglans regia var. kumaonica against Drechslera sorokiniana (Sacc.) Subram. was found to be more efficacious than J. regia var. kumaonica in prohibiting the spore pullulating mycelial enlargement inhibition (Chowdhury et al. 2008). Some researchers have also evaluated the antimicrobial, antifungal actions by selecting leaves of A. nilagirica. Besides that, the essential oil obtained from this plant has anti dermatophytes action against Epidermophyton floccosum, Trichophyton violaceum. Essential oil intermixed in polyethylene glycol proclaimed potency as the herbal antifungal compound in different dermatomycosis problems in guinea pigs. The extract persuades the effect within 14 days of pertinence; the minimum inhibitory concentration of oil has 200 ppm (Kishore et al. 2001).

\section{Antibacterial activity}

The phytochemical assessments of extracts the analysis expressed the presence of flavonoids, terpenoids, phenols, alkaloids, quinines, and tannins (Tajehmiri et al. 2014; Hiremath et al. 2011; Parameswari and Devika 2014; AddoMensah et al. 2015; Bereksi et al. 2018; Mamatova et al. 2019). Despite this, saponins and amino acids were found in methanol and ethanol extracts whereas carbohydrates specifically lie within methanol extracts, and glycosides hydrolyzable tannins were not found in the extracts. The susceptibility test showed the suppression of phytopathogens in hexane extracts. The phytopathogen of petroleum ether extract resulted in less suppression $(8-10 \mathrm{~mm})$ in correlation to other extracts $(10-14 \mathrm{~mm})$. The phytochemical assessments of entire extracts with petroleum ether revealed that it contains alkaloid derivatives (Erdogrul 2002; Shafaghata et al. 2009). Therefore, it is recommended that digression of alkaloid abundance in petroleum ether may be the source of reduced stimulation in phytopathogens. The minimum inhibitory concentration (MIC) analysis result of alkaloids against pathogens (Torres et al. 2002; Raghavendra et al. 2008) such as gram-positive and gram-negative bacteria denoted the availability of a wide range of antibiotic components. The methanol extracts demonstrated maximum suppression at the minimal concentration for the majority of the clinical pathogens as compared to other extracts. The MIC of methanol extract limits from 32 to $64 \mu \mathrm{g} / \mathrm{ml}$ for Enterobacter aerogenes, Salmonella typhi, Escherichia coli, Yersinia enterocolitica, Bacillus subtilis, Pseudomonas aeruginosa, and Proteus vulgaris. The phytochemical assessment of menthol extract demonstrated the existence of the majority of the components like terpenoids, alkaloids, flavonoids, phenols, amino acid, and tannins. Besides this, it has evidenced that alkaloids, amino acids, flavonoids, phenols, and tannin are recommended to be active antimicrobials (Brandao et al. 1997; Chakraborty and Brantner 1999; Shaheen et al. 2003; Chowdhury et al. 2008). Extracts of $A$. nilagirica intimated a wide range of antibacterial effects on the assessed microorganisms. Hexane extract demonstrated maximum prohibitory efficacy for the phytopathogens, as compared to methanol extract on Staphylococcus aureus, Escherichia faecalis, and Klebsiella pnumoniae (Ahameethunisa and Hopper 2010). Some specific reports reveal the antibacterial effects of $A$. nilagirica leaf extract and showed that Escherichia coli was more active than Klebsiella pneumoniae (gram-negative bacteria) whereas against gram-positive bacteria Bacillus subtilis and Staphylococcus aureus was found to be less active. The activity result suggests that the A. nilagirica extracts have shown profound activity as compared to the root extract of Aristolochia indica (Rao et al. 2006; Suresh et al. 2011).

\section{Antiulcer activity}

A peptic ulcer is increasing worldwide due to the emanation of unhygienic food and contaminated dietary supplements that adversely influence the health of human beings. Helicobacter pylori, one of the major causative microorganisms of duodenal ulcers, accounts for an inflammatory effect in gastric mucosa by enhancing the formation of cytokines, therefore, developing ulcer production (Zapata-Colindres et al. 2006; Marcus et al. 2013; Mohanty et al. 2018). Freezedried ethanolic extracts obtained from upper segments of A. nilagirica were ascertained for gastric antiulcer effects on rats. Ulceration was actuated by ethanol-hydrochloric acid and a $500 \mathrm{mg} / \mathrm{kg}$ concentration of extract defended the animal from gastric ulcer response. It has been stated that the $500 \mathrm{mg} / \mathrm{kg}$ concentration has a paramount level of gastric protection, mucus content was enhanced in proteins, which give rise to antiulcer action. Cimetidine was used as a control, which was not able to manifest any response on mucus secretion in the animal model (Suresh et al. 2011; Oliveira et al. 2014). A. nilagirica possesses many essential oils, as discussed earlier and these oils have an antiulcer effect as well as gastroprotective action, which was evidenced by its in-vitro study on rats (Moraes et al. 2009; Baananou et al. 2013). It was also authenticated that extracts of $A$. nilagirica on ulcer produced rats showed to prevent the ulcer formation by increasing the mucus concentration (Braquet et al. 1988; Mohanty et al. 2018).

\section{Larvicidal activity}

There has been a report that synthetically prescribed drugs in the market over a while has a resistance. Thereupon there is a requirement of another form of drugs such as herbal or ayurvedic formulation to overcome such types. A. nalagirica 
has already been conversated to incorporate numerous essential oils and other prominent therapeutically active chemical constituents, depending on these parameters, investigation was performed to analyze the larvicidal effect of this plant. It was ascertained that plant extract of $A$. nilagirica confirmed for noteworthy action against Aedesal bopictus and extract of A. nilagirica has been found beneficial larvicidal activities (Verma et al. 2006). The methanolic extract of artemisia has little effect on the protoscolices of hydatid cysts. Moreover, hydatidosis is a usual zoonotic sickness developed by the larval phases of Echinococcus granulosus (Faizei et al. 2015).

\section{Antiasthmatic activity}

Asthma is a disease of highly prevailing respiratory disorder that arises due to the susceptibility of adherent allergens existing in the atmosphere (Agrawal and Mehta 2008). Bronchial asthma is a complicated sickness, outlined by acute sensitiveness of trachea and bronchi to several stimuli characterized by acute, recurrent, chronic attacks of the prevalent shrinking of airways. Clinically, asthma is depicted by airway interruption that implicates inflammation and over the responsiveness of the pulmonary airways bronchial and is generally reversible (Cazzoletti et al. 2010). Asthma complies in children is due to respiratory tract infection, common cold, or viral infections (Singh et al. 2019). ROS is involved with the pathological process of asthma by actuating bronchial hyperreactivity inducing histamine liberation from mast cells mucus exudation from epithelial cells of the airway (Mali and Dhake 2011). Free radicals are assumed as an efficient instigating agent of various illnesses like bronchial asthma. Free radicals can ease detriment to intact biological membranes by infiltrating their glycoconjugates, proteins, lipids, and nucleic acids (Sahiner et al. 2011). A. nilagirica recommended as an antiasthmatic agent and was proved in Wistar rats to which ovalbumin solution ingested (Dorsch et al. 1987). These rats have manifested a potent therapeutic effect, which was shown by a low count of WBC (monocytes, neutrophils), less formation of nitrate ion, therefore diminishing the inflammation in lung regions of asthma induced animal model (Drazen 1997; Huntley and Ernst 2000). The in-vivo antiasthmatic reports confirmed that the A. caerulescens plant extract of aqueous suspension at a concentration of $200 \mathrm{mg} / \mathrm{kg}$ found potent activity as compared to a positively control-treated group that is ketotifen (Medici et al. 1989; Moran et al. 1989; Dyson and Mackay 1980; Kabra et al. 2000).

\section{Anticancer activity}

Devmurari and Jivani (2010) reported the anticancer activity of methanolic extract of A. nilagirica in Swiss albino mice, and the result was found to contain significant activity when compared to standard drug vincristine. Whereas the aqueous extract of Solanum nigrum along with species of genus artemisia such as A. vulgaris, A. nilagrica, A. parviflora produces a prohibitory action on cell development, colony accumulation of the human breast, prostate, colorectal cell lines. The cytotoxicity in cancer cells was due to internucleosomal DNA fragmentation, caspase-3-mediated Poly (ADP-ribose) Polymerase (PARP), ribose polymerase cleavage. The in-vitro results showed the methanolic extract of $A$. nilagirica has antineoplastic actions specifically in the breast, colon, and prostate (Devmurari and Jivani 2010; Devmurari et al. 2010; Nawab et al. 2011). The A. nilagirica fraction of ethyl acetate-hexane against DLD-1 human cancer cell lines showed good activity. HPLC-ESI-QTOF-MS/ MS discovery ascribes the recognition of cytotoxic agents that are to be implied for further preclinical testing (Sahu et al. 2018). Consumption of methanolic leaf extract of $A$. vulgaris is considered to execute a wide impact in all the phases of hepatocellular carcinoma (HCC). Hence, there has needed to elaborate the investigations for the employment of plant-originated agents as an effective anticancer compound in opposition to HCC for a peculiar drug evolution process (Emami et al. 2009; Nair and Varalakshmi 2011). Besides, artemisinins bioactive analogs can also be used as an antitumor agent against various types of cancerous cells, with lesser toxic effects on normal cells (Efferth 2015, 2017; Zhang et al. 2018; Numonov et al. 2019). The research on the bioactivity of different constituents of Artemisia species constituents has a good therapeutic against the treatment of cancer (Pezzuto 1997; Taherkhani 2015). Artemisia produces anti-angiogenic actions in tumor cell lines, and the methanolic extract of A. absinthium inhibits the growth of MCF-7, MDA-MB-231 cell which at different concentrations for nearly 3 days at a dose of $20 \mathrm{~g} / \mathrm{ml}$ and $25 \mathrm{~g} / \mathrm{ml}$ caused 50\% suppression in MDAMB-231 and MCF-7 cells respectively with control (Shoaib et al. 2017; Ahamad et al. 2019). It was also expressed that some extracts of artemisia varieties evaluated manifested a prominent effect on ER-apositive T47D cells and had a dual impact (stimulatory or prohibitory) on cell dissemination. Nevertheless, evaluation at concentration underneath $100 \mathrm{mM}$ or for $24 \mathrm{~h}$ accentuates cell progress, evaluating with artemisia spp. extracts at concentrations beyond $100 \mathrm{mM}$ for $72 \mathrm{~h}$ remarkably prohibited cell distribution. All extracts represented similar anti-cancer activity in a dose time-dependent pattern in HS578T cells. Whereas at lesser concentration growth of T47D cells, the prevent the growth of T47D cells at larger concentrations ( $>100 \mathrm{mg} / \mathrm{ml}$ ) for $72 \mathrm{~h}$ were notably higher than those of HS578T cells (Kaji et al. 1990; Wolin et al. 2010; Rabe et al. 2011; Choi et al., 2012; Choi et al. 2013a, b). The cytotoxic effects of A. fragrans, A. incana, A. absinthium, A. spicigera, and $A$. vulgaris. root, stem, leaf, and flower extracts 
on human embryonic kidney normal cell line (HEK293), and breast cancer cell line (MCF7) was determined using 3-(4,5-dimethylthiazol-2-yl)-2,5-diphenyltetrazolium bromide (MTT) assay at concentrations $(62.5,125,250,500 \mu \mathrm{g} /$ $\mathrm{ml})$. Methanol extracts of leaf, stem, flower, and the root of A. vulgaris and A. absinthium displayed remarkable anticancer activity, and the flower part showed greater cytotoxicity on MCF7 cell with an $\mathrm{IC}_{50}$ of $221.5>500 \mu \mathrm{g} / \mathrm{ml}$. Whereas the cytotoxic effect of A. absinthium, A. vulgaris, A. incana against MCF7 was 10-40\% higher than HEK293 cells. $A$. spicigera and $A$. fragrans were not able to demonstrate any cytotoxic effects on both cell lines while A. vulgaris and $A$. absinthium might have a higher new anticancer compound (Kaji et al. 1990; Nibret and Wink 2010; Zahi et al. 2010; Gordanian et al. 2014).

It was also found that $A$. sacrorum Ledeb has five types of flavonoid contents, namely kaempferol, Jaceosidin, luteolin, quercetin, and quercitrin. Two flavonoids obtained from the dichloromethane portion and other flavonoids from the $95 \%$ ethyl ether portions were analyzed for anticancer effects on human SK-Hep 1 hepatoma cancer cells human and HeLa cervical cancer cells. Two flavonoids have possessed significant anticancer activity against the HeLa cells line (Yuan et al. 2016). It was found that antiproliferative properties have been ascertained for some varieties of the genus artemisia. In that report, they observed the cytotoxic and apoptotic effects of $n$-hexane, dichloromethane, ethyl acetoacetate, $n$-butanol, water, and methanol extract of $A$. armeniaca on two myeloid cell lines, apoptosis-proficient HL60 cells, apoptosis-resistant K562 cells, and J774 cells as a control (Mojarrab et al. 2013). Several researchers revealed the identification of 130 constituents from the stem leaf of $A$. monosperma essential oil has an apoptotic cell in the human melanoma A375 cell line in-vitro anticancer effect on colorectal breast cancer cell lines by polyacetylene dehydrofal carindiol. Capillin (1-phenyl-2,4-pentadiyne), one more polyacetylene present in A. monosperma, was validated to persuade apoptosis in various human cancer cell lines like pancreatic MIA PaCa-2, colon HT29, lung carcinoma A549 cells, epidermoid carcinoma of the larynx HEp-2 (Stavri et al. 2004; Formisano et al. 2012; Khan et al. 2012; Solowey et al. 2014). Based on the above study artemisinin and its spinoffs have also been introduced as possible cancer treatments that affect multiple pathways. They are known to arrest the cell cycle, induce apoptosis, and slow cell proliferation. At lower concentrations, artemisinin is associated with the symbol of oncosis-like cell death. However, when the concentration increases, it promoted apoptosis in cells. The accumulation of artemisinin inside lysosomes and mitochondria has also been found to play a role in cell death (Du et al. 2010). As per the literature, the alkylating activity of artemisinin is due to the presence of the endoperoxide bridge in the structure of artemisinin that reacts with the heme group and iron. Artemisinin is capable to arrest the cell cycle, induce apoptosis, and slow cell proliferation. The accrual of artemisinin inside lysosomes and mitochondria has also been found to play a role in cell death (KonstatKorzenny et al. 2018).

The cytotoxicity of the different part extracts of $A$. absinthium was tested on the breast cancer cell lines (MDA MB-231 \& MCF-7) by MTT and lactate dehydrogenase (LDH) assay. The cytotoxic research along with proteome analysis indicate that extract stuffed polymeric nanoparticles (NPs) proficiently prohibits cell proliferation and persuade apoptosis also cell cycle arrest in the G0/G1 stage in both the breast cancer cell lines through appreciably regulating the expression of the key proteins concerned to the proliferation, apoptosis, tumor suppression and vesicular trafficking. (Mughees and Wajid 2019).

\section{Antihyperlipidemic activity}

Hyperlipidemia occurs due to lipid biotransformation induced by the increase of plasma concentration of various lipid lipoprotein that results in cardiac disease. It is accounted for as elevated serum total cholesterol, triglycerides, very-low-density lipoproteins, low-density lipoproteins, high-density lipoproteins (TC, TG, VLDL, LDL, HDL) which are responsible for congestive heart failure, cardiac arrest, myocardial infarction, cardiac strokes, atherosclerosis, coronary artery syndrome pancreatitis (Konda et al. 2013). Hypercholesterolemia is commonly accredited to be the crucial hazardous aspect of the progression of cardiovascular disorders. It has been assessed that hypercholesterolemia is the source of the augmented development of ROS. Oxidative stress produced by ROS imparts a principal role in the diagnosis of atherosclerosis as well as in coronary heart disorder. Considerable attention has been paid to naturally occurring compounds and their role in up-gradation for health fitness. The cholesterol-reducing property of comestible plants has been well measured and numerous plants have found profitable in, mitigating plasma cholesterol extent and raising the safety parameters (Kruth 2001). The A. vulgaris extract in hypercholesterolemic rats showed a remarkable reduction in $\beta$-hydroxymethylglutarylCoA reductase (HMGCoA) action with these excess fat diets treated animals control ones (Khan 2015). Therefore, it can be concluded that $A$. vulgaris extract produces hypolipidemic, anti-inflammatory, antioxidant properties and might be used for the treatment of atherosclerosis as well as cardiovascular-related diseases (Zhao et al. 2011; El-Tantawy 2015). It has been observed that the aqueous extract of roots has an explicit hypolipidemic effect in cholesterol diet-persuaded hyperlipidemia in rats (Rajendran et al. 1996; Yokozawa et al. 2003). Aqueous extract of the root can exhibit 
hypolipidemic activity same as the HMG-CoA reductase inhibitors such as rosuvastatin (Blois 1958).

\section{Antiepileptic activity}

Epilepsy is a prevalent mental ailment; common manifestations are seizures or convulsions. A disequilibrium between the aggravating overwhelming neurotransmitters is liable for the principal cause of seizures (Santilna et al. 2014). It influences around 7 million population in India and 50 million globally; around $40 \%$ of them found to be women (Kumar et al. 2012). About 50-80\% of people living with epilepsy are manageable with presently receivable anticonvulsant drugs, but these medications are still not capable enough to cure convulsions entirely in about $10-20 \%$ of the patients with epilepsy (Nsour et al. 2000). Most of the prescribed drugs by registered medical practitioners availed as antiepileptic compounds have deleterious influence sometimes life-threatening human situations are also realized by patients who are victims of epilepsy (Mittal et al. 2011; Sharma et al. 2013). That's why there is a great demand to innovate an alternative subsidiary antiepileptic agent from naturally occurring sources with potent therapeutic effects and lesser side effects (Smith and Bleck 1991; Nsour et al. 2000; Loscher and Schmidt 2006). The anxiolytic and anticonvulsant activities of the plant $A$. vulgaris was performed using the elevated plus-maze test and the Marble-Burying test (EPMMBT) diazepam $2 \mathrm{mg} / \mathrm{kg}$ used as standard. The methanol extracts produce antiseizure activities, elevating the time of quiescence for the initiating of the initial convulsion in all the assessments (Almeida et al. 2013). It has been noticed that ethanol extract of some species of the genus artemisia such as A. capillaris Herba (AC) has remarkable anticonvulsant action in electroshock as well as pentylenetetrazole (PTZ) seizure model. In comparison to diazepam, AC (100-200 mg/kg) did not modulate the locomotor performance and proceeding duration on the rota-rod, which denotes that it is unable to produce hangover, myorelaxation as well as not be sleep-inducing. Such dissimilarity between $\mathrm{AC}$ and diazepam is advantageous, stipulating that sleep induction and sedation is a general adverse effect of a few of the GABAergic neuronal anticonvulsants. Esculetin (ECT), therapeutically active medicinal constituents present in AC, imparting an anticonvulsant effect same as in the case of $\mathrm{AC}$, which designates that the effect of $\mathrm{AC}$ is as an outcome of ECT (Novack et al. 1978; Bum et al. 2001; Obniska et al. 2006; Woo et al. 2011). This has also been observed that ursolic acid, carnosolole, anolic acid intimated remarkable anticonvulsant effects against PTZ-induced seizures in mice. Oleanolic acid, carnosolursolic acid developed a dose-reliant enhancement in the duration of onset of tonic-clonic seizures, as a result, reduced the time of seizures (Khan et al. 2016).

\section{Antimalarial activity}

Malaria is one of the biggest life-intimidating diseases caused by Anopheles mosquitoes affecting a large number of populations globally (Barradell and Fitton 1995; Carter and Mendis 2002). It was studied that the effectiveness of antimalarial activity declared by selecting six different leaf extracts of A. nilagirica in solvents ( $n$-ethanol, petroleum ether, hexane, chloroform), besides this, methanol aqueous organic leaf extracts of A. nilagirica (Clarke) Pamp was found to be effective for Plasmodium falciparum (malarial parasite) (Czechowski et al. 2019). The antiplasmodial activity obtained the highest $50 \%$ inhibitory concentration $\left(\mathrm{IC}_{50}\right)$ after $32 \mathrm{~h}$ of gestation. This study reveals that the methanolic extract of leaf of $A$. nilagirica showed an in-vitro antiplasmodial effect on Plasmodium falciparum strain (FCR-3). In addition to this, the characterization of the medicinally active component from leaf extract may contribute to a molecule for malaria; their in-vivo studies also proved (Suberu et al. 2013). It can be concluded that $A$. vulgaris leaf extract has potent antimalarial activity against the Plasmodium yoelii. Due to resemblances between $P$. yoeli and human malaria parasites like Plasmodium vivax, Plasmodium falciparum, and Plasmodium yoelii can be utilized as another in-vivo model for human malaria (Carlton et al. 2002; Kodippili et al. 2011).

The antimalarial effect of the organic extract of A. vulgaris was for both antiparasitic and its other actions and at different doses $(250,500,1000 \mathrm{mg} / \mathrm{kg})$. There has been performed 4-day suppressive assay when extract has applied orally at $500 \mathrm{mg} / \mathrm{kg}, 1000 \mathrm{mg} / \mathrm{kg}$ doses to mice then it was found that there has been remarkably prohibited parasitaemia by $65.16 \%$ and $51.46 \%$. The A. vulgaris extract to administered to mice for 14 days (assay of sub-chronic toxicity), no ostensible symptoms of toxicity were seen. Hepatotoxicity serum glutamic-pyruvic transaminase (SGPT) has been estimated in respect of serum glutamic-oxaloacetic transaminase (SGOT) levels, renotoxicity (in respect of creatinine serum urea), haematotoxicity in respect of entire white blood cells and red blood cells (WBC and RBC), as well as differential leukocyte counts, were also precluded. Finally, A. vulgaris leaf extract was considered to be orally proficient, non-lethal and it can be an inexpensive origin of plant antimalarial (Kalkanidis et al. 2002; Mirjalili et al. 2007; Bamunuarachchi et al. 2013).

On another way, artemisinin obtained from A. аппиа is a potent antimalarial agent against chloroquine-resistant malaria. Root level study was taken into consideration to ascertain the antiparasitic action of an A. vulgaris in ethanolic leaf extract (AVELE) against Plasmodium berghei ANKA murine malaria model against falciparum malaria (Bamunuarachchi et al. 2013). Dichloromethane extracts of both species of A. spicigera and A. scoparia were reported 
to contain an antimalarial effect with $\mathrm{IC}_{50}$ at $0.7780 .999 \mathrm{mg} /$ $\mathrm{ml}$ for $A$. spicigera and A. scoparia. A. spicigera was found more potent rather than A. scoparia (Afshar et al. 2011). The hydroalcoholic aqueous extracts of $A$. апnи $\mathrm{L}$. were prominently found to be effective on malaria and can be utilized by inhabitants on a worldwide level to diagnose this disease, particularly in endemic regions where there is not sufficient budget to purchase potent new therapeutically active medicines (Mueller et al. 2000; Zime-Diawara et al. 2015).

The most extensively consumable, utilized antimalarial therapy is artemisinin-based combination therapies (ACTs), which are seen to be unadulterated, authentic, natural. Genuine artemisinin is found in combination form and isolated from the various genus of the artemisia plant prime one is A. апnиа (Weathers et al. 2014; Weathers and Towler 2014). Evaluating artemisinin along with sodium borohydride gives rise to dihydroartemisinin, which was considered to be an even more competent persuasive antimalarial agent than artemisinin (Basco and Le-Bras 1993; Weathers et al. 2011). Dihydroartemisinin persuades as the basis for the raise of oil-water-soluble analogs (Snow et al. 2001; De Ridder et al. 2008). Most of these analogs are dihydroartemisinin derivatives (Wongsrichanalai et al. 1997). The effectiveness of artemisinins analogs has been assessed by the in-vitro method with different strains of Plasmodium falciparum (Payne 1987; Su and Miller 2015). It has observed that the drug concentration required to prohibit $50 \%$ of the parasite's activity, the $\mathrm{IC}_{50}$, artemisinin has persistently been considered 2-5 times less efficacious than its analogs dihydroartemisinin, artesunate, and artemether (Hassan et al. 1996; Delabays et al. 2001; Medhi et al. 2009). Thereupon, larger doses of artemisinin are needed to attain a similar antimalarial activity. WHO endorses ACTs as the fundamental basic remedy for easygoing and apparent Plasmodium falciparum malaria, additionally for chloroquine-resistant Plasmodium vivax malaria (Barradell and Fitton 1995; Snow et al. 2005). Artemisia herbal medications have also been recommended for elimination as well as avoidance of different malarial strains (Carter and Mendis 2002; WHO 2019). A. indica, which has flavonoids such as sakuranetin, 7-methoxy aromadendrin, also showed extreme antiprotozoal activity (Ribeiro et al. 1997).

\section{Anti-inflammatory activity}

The leaf extract obtained from the plant manifested to protect the human red blood cells (HRBC) with $74.63 \%$ at $20 \mu \mathrm{g} / \mathrm{ml}$ concentration and minimum hemolysis seen about $25.37 \%$ in a hypotonic solution as compared to standard drug diclofenac (Ghisan et al. 1991; de Souza et al. 2016). Finally, by employing a UV-Visible spectrophotometer hemoglobin concentration of the supernatant was assessed at $560 \mathrm{~nm}$ (Anosike et al. 2012). It was proved that the extract selected from the leaves of A. nilagirica (Clarke) Pamp was effective for in-vitro anti-inflammatory activity and the leaf extract displayed utmost conservation scanty hemolysis of the $\operatorname{HRBC}(74.63 \%, 25.37 \%$, serially) at a cumulation of $200 \mu \mathrm{g} / \mathrm{ml}$ in hypotonic suspension. Moreover, at a cumulation of $50 \mu \mathrm{g} / \mathrm{ml}$, the extract manifested extreme hemolysis of $52.89 \%, 47.11 \%$, serially, and was collated with the reference drug that was $<91.18 \%$ protection $16.68 \%$ hemolysis. The extract demonstrated membrane stabilization by suppressing hypotonicity and lyses of the erythrocyte membrane (Chou 1998). Furthermore, immobilization of the extract can immobilize lysosomal membranes, which play an important role in inflammatory responses by decreasing the lysosomal ingredients of triggered neutrophil-like bactericidal enzyme proteases (Murugasan et al. 1981). It also can hamper these proceedings, which may induce or elevate the intracellular ingredients (Iwueke et al. 2006).

\section{Hepatoprotective activity}

A maximum number of the drugs, food water components are metabolized in the liver. Vital tasks of the liver concerns with the metabolism of fats, carbohydrates, proteins along with their detoxification process. Besides this ejection of bile, the collection, as well as detoxification of various drugs and xenobiotics, proceeds through the liver. The hepatic reticuloendothelial system (RES) clears stimulated clotting factors, proteolytic enzyme/inhibitor complexes, and fibrin-fibrinogen cleavage proceeds (Bansal et al. 2014). Liver-related diseases are one of the biggest health disorders in the world; the pathogenesis of hepatic ailments as well as the role of oxidative stress inflammation are well accomplished (Malhi and Gores 2008; Tacke et al. 2009). By decreasing the chain reactions of oxidation inflammation steps could be a significant and useful therapeutic approach for the prohibition of liver abrasion and damage. In-vivo model is used for the exploration of new hepatoprotective compounds that have prescribed rodent model of liver injury caused by carbon tetrachloride $\left(\mathrm{CCl}_{4}\right)$, a chemical hepatotoxin that produces a free radical-mediated hepatocellular harm reparation (Weber et al. 2003; Upur et al. 2009; Amat et al. 2010). Qualitative as well as quantitative phytochemical analysis of the aqueous extract of A. absinthium L. (AEAA) was implemented with the help of thin-layer chromatography and spectrophotometric assays which assess in-vivo hepatoprotective action of the aqueous extract of A. absinthium L. (AEAA). The action of AEAA inhibits acute liver abrasion, which may be due to its immunomodulatory and antioxidative properties (Amat et al. 2010). The hydroethanolic extract of $A$. scolari preserves the structure of the hepatocellular membrane which is because of the acetaminophen-prompted up-gradation in serum glutamic oxaloacetic transaminase 
(GOT) and glutamic pyruvic transaminase (GPT) extents in rats and mice. Thus, this study concludes the conventional utilization of the A. scoparia plant in hepatobiliary ailments. Hydroalcoholic extract of $A$. dracunculus reinstated the elevated serum enzyme extents, reduced liver antioxidant markers, strived, and proficient antioxidant activity under in-vitro situations demonstrating that it has hepatoprotective antioxidant efficiencies in $\mathrm{CCl}_{4}$-intoxicated rats (Mankani et al. 2005; Gilani and Janbaz 1993). The hepatoprotective property of hydro-alcoholic extracts of aerial parts of $A$. dracunculus (HAAD) caused by extenuated lipid peroxidation improved protection of the hepatocytes against reactive oxygen species (ROS) (Lopez et al. 2017). The histopathological reports also proved the effectiveness of the plant extract. In addition to this, the antioxidant activity of $A$. dracunculus supports the therapeutically and medicinally active constituent of this plant as well as recognizing their functioning pattern (Kordali et al. 2005; Zarezade et al. 2018). The efficacy of the crude extract and aerial segments of $A$. vulgaris have been identified against lipopolysaccharide (LPS) and galactosamines (D-GalN) induced hepatitis in mice. These experiments proved the conventional use of $A$. vulgaris for numerous liver-related diseases (Gilani et al. 2005). Different xenobiotics studies confessed to elicit hepatotoxicity, produced by paracetamol ( $p$-hydroxy acetanilide or PHA) and carbon tetrachloride $\left(\mathrm{CCl}_{4}\right)$ on the animal model which showed mechanisms of actions for liver impairment. Watersoluble polysaccharides, polypeptides, organic acids, and flavonoids for the liver protective actions of $A$. capillaris has also elucidated (Han et al. 2006; Choi et al. 2013a, b; Jiao et al. 2016).

\section{Antitubercular activity}

Tuberculosis (TB) is disease-causing mortality globally around 9 million population and affecting 2 million people yearly (Elhassan et al. 2013; Ngadino et al. 2018). Mycobacterium tuberculosis is one of the fatal diseases involving a large number of the human population and drug resistance also occurs (Jimenez-Arellanes et al. 2014). A large number of secondary plant metabolites are confirmed to retain antitubercular activity (Negi et al. 2010). It was seen that methanolic extracts of $A$. capillaries and hydroquinoneursolic acid have shown inhibitory actions against many strains of Mycobacterium tuberculosis (MTB by using MGITTM 960 resazurin assay. Phytomolecules have been additionally assessed by transmission electron microscopy (TEM). Hydroquinone (HQ) and ursolic acid (UA) stops the growth of both vulnerable resistant species of $M$. tuberculosis (Jyoti et al. 2016). Some antimycobacterial activity reports that $20 \%, 40 \%, 70 \%$, and $96 \%$ ethanolic extracts of the root of A. absinthium decrease $100 \%$ growth inhibition of Mycobacterium tuberculosis strains with $96 \%$ ethanolic extract.
However, the mechanism of the plant is needed for prevention as well as control of disease (Hojageldiyev et al. 2019).

\section{Antihypertensive activity}

The antihypertensive activities of $A$. scoparia (AS) on hypertensive rats (ASHR) showed splendid activity (Cho et al. 2015). A. persia (AP) is used in folk medicine for antihypertensive potency. The aqueous methanolic extracts of $A P$ are used for obtaining cardiovascular effects, for blood pressure (BP), cardiac rate (CR) of normotensive ephedrine induced hypertensive rats. High blood pressure was decreased by a single sip of ephedrine ( $40 \mathrm{mg} / \mathrm{kg} / \mathrm{IM})$ to uplift BP 20-30 mmHg. Aqueous methanolic extracts were given at a dose of $(300,400$, and $500 \mathrm{mg} / \mathrm{kg}$ ) by gavage process excellent results for the systolic blood pressure of normotensive rats observed at $400 \mathrm{mg} / \mathrm{kg}$ afterward $20 \mathrm{~min}$ consummation while others don't influence diastolic BP or HR compared with enalapril (30 mg/kg). Oral consummation of AP extracts next 20 min systolic BP in normotensive hypertensive rats, on the contrary, the aqueous extract of AP extenuated the BP of hypertensive rats much faster as that of enalapril (Ghisalberti et al. 1998; Esmaeili et al. 2009; Ahmed et al. 2017). Another variety of the genus artemisia that is A. pallens has successfully been reported in Ayurveda for the treatment of high blood pressure (Pavithra et al. 2018). Moxibustion is a conventional and East Asian medical treatment that contains $A$. vulgaris with acupuncture treatments (Kim et al. 2010; Zhou et al. 2018). One more distinct species of the genus artemisia that is A. herba-alba recognized for its therapeutic medicinal characteristics, it was consumable in an easy way and available in both traditional as well as in contemporary medicine. A. herba-alba was utilized as a folk remedy for the prevention of arterial hypertension (Mohamed et al. 2010; Samaha et al. 2019).

\section{Antidiabetic activity}

World Health Organization (WHO) describes diabetes as a disturbance in the metabolism of carbohydrates, fats protein; generated by the deficit of insulin deliverance, or decreased susceptibility of the tissue to insulin (Kavitha and Dattatri 2013). Allopathic medications are not enough, therefore naturally occurring medicinally active plants impart a crucial role in the cure of diabetes mellitus (Dabe and Kefala 2017). The aerial root extracts of A. dracunculus were evaluated for antidiabetic effect in streptozotocin (STZ) promoted diabetic rats. It showed a promising and remarkable antihyperglycemic effect when compared with standard drug glibenclamide at a dose of $0.25 \mathrm{mg} / \mathrm{kg}$. The plant was capable of enacting antidiabetic, along with antihyperlipidemic properties (Samyal et al. 2011). The antidiabetic efficacy of A. amygdalina being effective in hyperglycemia 
may successfully control metabolic disorder and endorse its medicinal therapeutics and conventional uses (Sidhu and Sharma 2013; Ghazanfar et al. 2014). A. dracunculus L. was found to contain a hypoglycaemic effect by numerous investigators (Ribnicky et al. 2009; Wang et al. 2011). Wang et al. (2011) ascertained a particular A. dracunculus L. plant for its prominent insulin susceptibility as well as insulin resistant (IR) signaling in insulin-resistant KK-Ay mice but are unable to describe the appropriate cellular mechanism (Coman et al. 2012).

\section{Antiparasitic activity}

Parasites cause different types of tropical illnesses like malaria, helminthiasis, onchocerciasis, schistosomiasis, lymphatic filariasis, trypanosomiasis, leishmaniasis. It affects around 1-2 billion people, which gives rise to a million death each year (Wink 2012; Nikpay and Soltani 2018). Furthermore, these fatal and harmful parasitic diseases, numerous ectoparasites adversely influence salubrity as well as the normal health of human beings, which accommodate slice, fleas, mites, bed bugs, various myiasis causing Diptera (Nussbaum et al. 2007; Peters and Pasvol 2007). Several human parasites are spread and expended by arthropod mediators, which also might be a goal regarding subsidiary metabolites containing insecticidal properties (Le et al. 2018). Hymenolepis nana is a usual intestinal tapeworm, which adversely and skeptically influences the life of human beings. Drugs used against this disease are niclosamide, nitazoxanide, praziquantel (PZQ). An aqueous extract $A$. absinthium against $H$. nana was examined in-vitro, $15 \mathrm{mg} /$ $\mathrm{ml}$ of the extract as a test, and $1 \mathrm{mg} / \mathrm{ml}$ of PZQ as standard showed significant anthelmintic activity. The in-vivo examination of A. absinthium was carried out, mice have distributed into untreated, PZQ treated (400-800 mg/kg). Before and after evaluation, egg per gram of feces (EPG) was noted; the decreased rate ratio of the (EPG) worm was counted. The promising outcome obtained was comparable with praziquantel promoted worm paralysis, inanimation, lipid congregation, etc. decrease in the EPG worm encumbrance was observed and noted. A. absinthium has been found to give promising results, comparable to $\mathrm{PZQ}$, additional studies imparting separate extracts, active constituent concentrations across diverse parasites might be accompanied (Beshay 2018). Herbs have been successfully applied and selected for centuries against endoparasiticides. Food-Drug Administration along with the National Administration of Drugs, for Food Medical Devices (FDA, ANMAT) monitored a few of the plants considered in various research for Artemisia absinthium, black walnut nut, wormwood as medicinally approved fruitful herbs with vermicide action (Griselda et al. 2016; Osorio and Garcia 2019). The hydroalcoholic extract of $A$. absinthium set forth a promising and prodigious antileishmanial activity after $48-72 \mathrm{~h}$. The $\mathrm{IC}_{50}$ for the alcoholic extract of $A$. absinthium was reported at $56 \mathrm{mg} / \mathrm{ml}$ and $51 \mathrm{mg} / \mathrm{ml}$ cumulations of amastigote sand promastigotes. The decrease in NOs has been observed at 100 and $50 \mathrm{mg} / \mathrm{ml}$ (Aberham et al. 2010). The previous one was attained at $60.8-58.8 \mathrm{ng} / \mathrm{ml}$ next $24-48 \mathrm{~h}$ and later on for $72 \mathrm{~h}$ (Rahiminejad et al. 2018).

Artemisia herba-alba has proclaimed the anthelminthic effect as it has decreased egg shedding worm encumbrance in the infected birds in the same way as that of albendazole. The herbal extract improved feed conversion ratio (FCR) around further infected groups (positive control albendazole treated group) and it was observed that no detrimental actions were found on the liver and kidney, of treated poults. These results suggest that $A$. herba-alba could be utilized and availed for the management and prevention of heterakid (nematode worm) infection. Efforts for the separation and identification of the medicinally active ingredients accountable for such activities are still in the development process (Pohlit et al. 2011). Later on, investigations have tried to find out the precise mode of action (Seddiek et al. 2011). Parasitic infections in a different manner (food, water, vegetables) can influence the lives of human beings, and cause gastrointestinal problems, malnutrition disorders, anemia, allergies frequently even life denunciatory. The employed terms for treating all of these complications comprise herbal medicine, medicinal plants, anthelmintic drugs, antinematoda, anticestoda, antitrematoda induced infections are also prevented by the same (Porrini et al. 2011; Bahmani et al. 2014). Some investigations regarding the crude extracts of $A$. absinthium were found to be effective in in-vivo enlargement, progress, and improvement of the parasite that is syphacia. A. sieberi was proposed as one of the huge imposing medicinal active constituents possessing plant against the coccidiosis in the chickens that are contaminated with Eimeria acervolina, and Eimeria tenella except for Eimeria maxima microorganism (Arab et al. 2006; Youssefi et al. 2011).

Artemisinin (ART), and their several derived analogs possess antimalarial and antischistosomal compounds originated from A. аппиа L., ART, and against another parasitic protozoan (Ataei and Delnavaz 2019). ART and their numerous analogs are used as protozoan parasites in in-vitro, and in-vivo, incorporating, Trypanosoma spp, Leishmania spp, Babesia spp, Cryptosporidium parvum, Naegleria fowleri, Giardia lamblia, Neospora caninum, Toxoplasma gondii, Eimeria tenella, and Acanthamoeba castellanii, etc. considered as auspicious substitutes for prohibiting nonmalarial protozoan infections in developing nations (Loo et al. 2017). A. absinthium has proficient flavors, thus has very potent actions in animals including ruminants (Beigh and Ganai 2017). The chemical constituent ivermectin have investigated and identified and later on was considered as a strong newly emerged antiparasitic compound at Merck 
Shape and Dome Research Laboratories (MDRL), afterward chemically altered avermectin known as ivermectin, have been developed and found to be efficacious against parasitic infection (Burg et al. 1979; Campbell et al. 1979; Chabala et al. 1980). Ivermectin is a semisynthetic compound and has a good therapeutic index as well as safety (Campbell et al. 1983; Campbell 2012; Tambo et al. 2015).

\section{Antidepressant activity}

Several investigational reports have demonstrated the medicinal property of phenolic compounds, chlorogenic acid, syringic acid, caffeic acid, ferulic acid, vanillic acid, kaempferol, rutin, luteolin, quercetin, and catechin in the cure of mental illness. Since these secondary metabolites are considered as the phenolic agents emerged from $A$. dracunculus and Stachys lavulifolia. Antidepressant properties of the extracts were examined in the forced swimming test (FST) along with the tail suspension test (TST) (Ahangar et al. 2011; Akkol et al. 2019). An open field test was performed to examine the usual locomotor actions in ice complying treatment with the extracts. Remarkable activity between the phenolic contents of the extracts was not observed, whereas S. lavulifolia demonstrated good activity due to excess flavonoid contents. Animal treated with extracts reduced the immobility duration in FST, as well as TST, collated to the vehicle group excluding any promising impression on the locomotor action of animals (Aslam 2016). Moreover, S. lavulifolia at $400 \mathrm{mg} / \mathrm{kg}$ concentration demonstrated enhanced efficacy in both tests connoted to $A$. dracunculus (Khosravi et al. 2017). Some important research reports contributed prodigious substantiation on the antidepressant resembling the action of both extracts, which could be concerned with flavonoids as the prime constituents of the extracts (Jahani et al. 2019).

The ethanolic extract of $A$. апnиa $\mathrm{L}$. the essential oil (AEO) attained by hydrodistillation, both with serene leaves for the forced swimming test (FST), the open-field test (OFT) are evaluated for antidepressant activity. A. аппиа essential oil or raw ethanol extract extended the calmness duration in the FST extenuated another function (ambulation, rearing, exploration, and grooming) in the OFT in livestock, along with AEO and pentobarbital used as a standard drug as satisfactorily, however, the essential oil has shown a noticeable action. Inspecting these results, this is probabilistic to propound that A. апnиа crude ethanol extract essential oil is responsible for the suppressor of the central nervous system (CNS) (Perazzo et al. 2008).

Numerous findings of some of the recently performed discoveries intimate the antidepressant effects of $A$. absinthium in the FST and TST model of depression. A. absinthium remarkably attenuated the quiescence duration in FST as well as TST. The extract has been found capable to express auspicious and providential outcomes but disparate extents of antioxidant effects in some models are also considered. Further investigations are required to determine its appropriate mechanism (Mahmoudi et al. 2009). A. absinthium has been proved to accomplish antidepressant action in a mouse model of tail suspension forced swimming tests (Rahman et al. 2017). Chlorogenic acid separated and taken away through $A$. capillaries has demonstrated to acquaint appreciable antidepressant activity (Park et al. 2010; Khan et al. 2016).

\section{Gastroprotective activity}

Gastritis is indicated by the indication such as irritation, inflammation, or abrasion of the gastric epithelium and eventually can cause cancer (Kangwan et al. 2014; Kuipers 2015). Gastrointestinal inflammation is biochemically sevenfold sophisticated as well as intricated, might be gendered through oxidative bunts issuing as a result of enormous stress, surplus drinking, or the exploiting of certain drugs (Fakhoury et al. 2014). The generation of reactive oxygen species (ROS), namely oxygen ions, peroxides, and free radicals, might be a grave hurdle in gastrointestinal homeostasis so far as their huge chemical reactivity (Tian et al. 2017). In that case, ROS formation can give rise to gastric mucosal harm, to that lipid peroxidation is abundantly extended (Rezaie et al. 2007). Lipid peroxides generally degraded to malondialdehyde (MDA), 4-hydroxynonenal (4-HNE), and concentrations, unfold ROS-reliant gastric bunt. It has been ascertained in some research reports that a concentration of the aqueous leaves extracts of $A$. herba alfa against aspirininduced ulcer where the extract was seems to be healing of ulcer (Abushwereb and Tolba 2016).

It was investigated by some researchers about the gastroprotective activity of an isopropanol extract from the aerial segments of A. princeps (IPAP) and designed as a gastroprotective floating tablet of IPAP (IPAP-FR) and obtained gastroprotective results against the excessive gastric mucosa secretion (Kim et al. 2017). The medicinally active constituent that is scoparone (6,7-dimethoxycoumarin), a coumarinderived component obtained from Hericium erinaceus with A. capillaries, confirms an efficacious gastroprotective impact on gastric secretion induced by $\mathrm{HCl} /$ ethanol in rats (Son et al. 2015). Aqueous extract of A. capillaris (AEAC) against the gastric mucosal lesion (Yeo et al. 2018). The therapeutic potency of AEAC was seen by employing the gastric ulcer index and histological assessments, the mucosal impairment was indeed commanded by therapy with 200 or $400 \mathrm{mg} / \mathrm{kg}$ AEAC. It has not possessed acid-nullifying property in-vitro unable to stop histamine release in HMC-1 mast cells. In gastric mucosa, AEAC, furthermore, outstandingly deprived lipid peroxide production by superoxide dismutase (SOD) stimulation. AEAC also helps in the formation of 
proinflammatory cytokines, namely interleukin-1 $\beta$ (IL-1 $\beta$ ), interleukin-6 (IL-6) via nuclear component kappa B (NF$\kappa B$ ) downregulation (Soufli et al. 2016; Haq et al. 2019). The results suggest that AEAC prohibits inflammation continues as well as perpetuates oxidant/antioxidant homeostasis, in a gastro-protection to $\mathrm{HCl} /$ ethanol-instigated gastric and can be availed as a proficient drug for gastritis and gastric ulcer.

\section{Antiviral activity}

In our review, we have briefly concise the antiviral properties from various naturally occurring resources and herbal remedies in contrast to a few distinguished viral microorganisms accompanying coronavirus $(\mathrm{CoV})$, hepatitis $\mathrm{B}$ virus (HBV), measles virus (MV), dengue virus (DENV), enterovirus 71 (EV71), hepatitis $\mathrm{C}$ virus (HCV), coxsackievirus (CV), human immunodeficiency virus (HIV), influenza virus, herpes simplex virus along with respiratory syncytial virus (RSV) (Karamoddini et al. 2011; Lin et al. 2014). Here, we have principally emphasized coronavirus disease 2019 (COVID-19), as it is extremely and severely exploring conditions globally at present. Severe acute respiratory syndrome (SARS) coronavirus (SARS-CoV) is an offbeat and unique virus that has stirred up enormously and profoundly globally, word wide to this current era (Cheng et al. 2007). There is no antiviral remedy or vaccines that have been achievable as long as for prevention of this contingent as well as fatal ailment, which can be prevented by obeying social distancing and taking adequate and preliminary precautions exclusively (Yang et al. 2020). The corona viridae dynasty, an enwrapped RNA virus dynasty, in addition to copious specifically, human coronaviruses ( $\mathrm{HCoV}), \mathrm{HCoV}$ causes respiratory problems such as bronchiolitis, bronchitis, and pneumonia, with decreased immunity (Geller et al. 2012). Dissemination of coronaviruses on account of infected drained superficies has been presumed accompanying auto-exegesis of the mucous integument of the mouth, nostrils along with eyes, reiterating the ponderability of comprehensive and sightedness discerning of coronavirus stubbornness on defunct superficies (Kampf et al. 2020). Vero E6 (BJ001, BJ006) sorts of SARS-CoV treated with A. annua that is a Chinese medicinal herb (Li et al. 2005; Cheng et al. 2007). Some crucial and conspicuous species of A. annua in conjunction with Pyrrosia lingua and Lindera aggregate demonstrated the anti-SARS-CoV activity (Yang et al. 2020). Adscititious, several kinds of anti-coronaviral compounds described and recognized out of possession of Traditional Chinese Medicine (TCM) herbs, albeit the mode of functioning of these newly identified compounds, were not accomplished till date. The extracts prepared from A. апnиa plant might be given in the form of infusion to accomplish an abundant range of antiviral properties notably against coronavirus, dengue virus, and herpes simplex virus
(Mesa et al. 2015). Moreover, global studies reported that many medicinal herbal ingredients have revealed antiviral activities against coronaviruses and their primary mechanism of action seems to be through the inhibition of viral replication (Jassim and Naji 2003). China has commonly used traditional Chinese medicinal herbs for the treatment of SARS effectively in many cases. However, there is no substantial evidence yet on the clinical effectiveness of these for Covid-19 infected patients (Luo et al. 2020). The genus artemisia revealed that traditional herbal remedies that emerged for this genus are productive and worthwhile against SARSCoV infectious ailments (Haq et al. 2020).

\section{Miscellaneous activity}

The genus artemisia plants contain sesquiterpene that seems too effective in female-related sexual problems. Mugwort remedial treatment is pleasant secure for menopausal apart from hormone restoration therapy. Mugwort treatment decreases hyperactivity disorder, found to be safe and intact for the children when compared to amphetamine or methylphenidate treated therapy (Adams et al. 2012). Artemisia plants also bear a noteworthy as well as prodigious action against numerous tropical ailments such as schistosomiasis, leishmaniasis, and Chagas disease, etc. (Lutgen 2019).

The ethanolic aqueous extracts of A. nilagirica and $A$. parviflora have been employed for the anti-Alzheimer effect. A different test for catalepsy (bar test), locomotor action (actophotometer test) muscle mobility (rotarod test) proves for antiparkinsonian effect, and also possesses impressive and emphatic neuroprotective activities (Sengupta et al. 2011; Rios et al. 2016). A. absinthium was employed in the formulation of the drink, presently have been restricted in a maximum number of nations because of neurotoxicity (Lachenmeier and Uebelacker 2010; Lachenmeier 2010). Arglabin was separated as an extract from A. myriantha, possessing efficacious immunomodulatory effects (BottexGauthier et al. 1993; Adekenov 2016).

Extracts obtained from A. аппиа L. (EAA) plus methotrexate-leflunomide were employed for the treatments of rheumatoid arthritis (RA) (Min et al. 2016). Extracts of $A$. afra was correlated with medication therapy of tuberculosis (TB) and some commonly arises manifestations of TB (Semenya and Maroyi 2013). Haemoptysis is suppressed by some reports of investigators (Han et al. 2018). A. scoparia Waldst. Kit (Asteraceae) is employed even as an effective remedy for some serious diseases such as hepatitis, jaundice, inflammation of gall bladder \& this plant in conjunction with other herbs have been applied for the inhibition of cholagogue (Ryu et al. 2018). This plant also capable of eliciting significant insecticidal activity. Decoction has been successfully formulated from this plant used topically 
to cure infectious wounds in Pakistan (Negahban et al. 2006; Tareen et al. 2010).

One species of this genus A. herba-alba was also confirmed to function as a vermifuge by lowering the egg and worm load of Heterakis gallinarum eggs in Haemonchus contortus and infected birds. (Ninditya et al. 2020).

A. verlotiorum Lamotte, (Asteraceae), an entire plant might be used for the cure and prevention of leucorrhoea, tonic emmenagogue, dermal infections, fever, influenza (Sussman 1980; Wong Ting Fook 1980; Adjanohoun et al. 1983; Fakim 1990; Gurib-Fakim et al. 1993, 1996a, b). The chemical constituents obtained from this pant also employed as hemostatic, stomachic, to control dysmenorrhea, metrorrhagia, antispasmodic and skin ailments. The leave contents of the plant suggest an essential oil which contains abundant chemical constituent like germacrene that obtained in the yield of around 23.6\% (Gurib-Fakim et al. 1996a, b, 1997). A. аппиа plants kill the parasites integrated with malaria and dengue fever. Explorers commenced by imparting artemisia extract against the parasite larvae originated from the mosquito's kin Anopheles stephensi female (malaria) together larvae originated from Ades aegypti which disseminates dengue fever. The extract of $A$. апnи a demonstrated the tenacious larvicidal effects, remedy for fever, liver gall bladder disorders, now it is being assessed for flatworm infection as well as contamination produced by schistosomiasis (Biesen 2010; Hossain et al. 2014; Noori et al. 2014; Darvishpor et al. 2018; Zeb et al. 2018). It is also estimated by some explorers that a particular methanol extract of $A$. pallens mitigates APAP (Acetaminophen) persuaded renal poisoning in rats via showing its anti-inflammatory as well as antioxidative properties (Honmore et al. 2014). A. capillaris plant is also used to control atopic dermatitis (AD) that is an inflammatory, chronically relapsing, and non-contagious stage. It is also employed as medication for treating pruritic and skin related problems (Ha et al. 2014).

\section{Toxicological studies of artemisia}

Ogbole et al. (2014) performed acute toxicity studies of hexane leaf extract of Artemisia annua using rats at a dose of $1000,2000,2500 \mathrm{mg} / \mathrm{kg}$ intraperitoneally. They measured and observed different parameters like food and fluid intake, which was decreased, whereas urine and fecal output increased. Hematological parameters viz red blood cells, white blood cells, hemoglobin, mean corpuscular volume, packed cell volume, mean corpuscular hemoglobin, mean corpuscular hemoglobin concentration, platelets, and lymphocytes showed some significant changes. The lethal dose $\left(\mathrm{LD}_{50}\right)$ of the extract was found to be $2750 \mathrm{mg} / \mathrm{kg}$ body weight. Overall studies showed low toxicity in short time treatment. It was declared that
A. parviflora did not elicit any kind of harmful manifestations or demise in the acute toxic toxicity study, revealing that an $\mathrm{LD}_{50}>1 \mathrm{~g} / \mathrm{kg}$ body weight (Paramakrishnan et al. 2012). On the other way, A. nilagirica oil has been disclosed to be more toxic, evincing $100 \%$ mycelia inhibition of all test fungi (Sonker et al. 2015).

The ethanolic extracts of aerial parts of A. abyssinica and A. inculta were studied for acute and chronic toxicity was done by Qureshi et al. (1990). In A. inculta extract showed no signs of toxicity however at a dose of $3 \mathrm{~g} / \mathrm{kg}$ it showed CNS stimulation, rapid respiration, which might be due to the presence of bitter principles in the extract. During chronic toxicity studies, two animals were found to have eye inflammation; otherwise, no signs of any abnormality; and mortality was observed as compared to the control. This plant extract did not show any signs of a spermatotoxic effect. A. abyssinica treated animals did not show visible toxicity, whereas at $3 \mathrm{~g} / \mathrm{kg}$ some decreased locomotor activity. Chronic treatment with this extract, four female mice were found to be anemic. Alopecia was noticed for one male in its genital region, and one male animal suffered from forelimb inflammation and constipation. However, no significant and no weight gain and acute mortality were observed up to $3 \mathrm{~g} / \mathrm{kg}$ p.o but a significant spermatotoxic effect was observed.

In-vitro and in-vivo animals and human clinical studies revealed that the genus artemisia has artemisinin that showed reproductive toxicity and neurotoxicity which include hearing loss, ataxia, and tremor. This was confirmed when a $20 \mathrm{mg} / \mathrm{kg} /$ day of artemether was given i.m. to groups of 3 male Beagle dogs for 5 and 30 days, respectively. Symptoms of neurotoxicity were observed from test day 23 onwards that includes hypochromic, microcytic anemia. After 5 days neuropathic alteration like neuronal and secondary axonal damage occurs in the cerebellar roof, pontine and vestibular nuclei, and in the raphe/paralemniscal region. Neuronal damage was found in all animals at 40 and $80 \mathrm{mg} / \mathrm{kg}$ following i.m. treatment. At $20 \mathrm{mg} / \mathrm{kg}$ it showed minimal effects in 5/8 dogs only, demonstrating that this level was close to tolerated exposure (Nontprasert et al. 1998; Classen et al. 1999; Medhi et al. 2009). A comparison of neurotoxic potential of the artemisinin and its derivatives using adult swiss albino mice model for 28 days via oral and the parenteral routes. Neurotoxicity or death in $50 \%$ of animals $\left(\mathrm{ED}_{50}\right)$ was observed by the intramuscular route for artemether and artesunate at $300 \mathrm{mg} / \mathrm{kg} /$ day compared to $50 \mathrm{mg} / \mathrm{kg} /$ day .

When oral administration of the artemether showed an increase in neurotoxicity and mortality compared with the aqueous suspension, $\mathrm{ED}_{50}=150 \mathrm{mg} / \mathrm{kg} /$ day. These results indicated that once-daily oral administration of artesunate or artemether is relatively safe, presumably because the CNS is exposed transiently, whereas regular introduction either from depot i.m. injection of an oil-based drug or constant oral 
intake carries produces higher neurotoxic potential (Nontprasert et al. 2000).

The artemisinin also showed genotoxicity and reproductive toxicity the genotoxic profile of in-vitro bacterial mutagenicity and an in-vivo bone marrow micronucleus test were conducted in mice. Concentrations of up to $300 \mathrm{~g}$ per plate in the bacterial assay, and doses of up to $845.6 \mathrm{mg} / \mathrm{kg}$ in the micronucleus test were shown to be without effect, and the compound can thus be regarded as devoid of genotoxic activity. Dihydroartemisinin, the principal metabolite of artemisinin showing embryo death and abnormalities in early pregnancy in-vitro and in-vivo experimental models. Oral administration of artemisinin can adversely affect postimplantation development at different periods of pregnancy (Boareto et al. 2008; Longo et al. 2006; White et al. 2006).

\section{Some allied species of genus artemisia}

Some important medically, as well as therapeutically active species of the genus Artemisia, is very briefly enumerated below.

Artemisia absinthium L.: Popularly called "wormwood," is a yellow-flowering plant found throughout numerous areas of Europe Siberia, is entrusted for its antiparasitic properties is used as a medication to cure indigestion and anorexia. The aerial segments are prompted to formulate various gastric herbal formulations, in dietary complements, also involved in alcoholic potations, for instance, absinthe preparations, those are delighting a rejuvenation (Lachenmeier 2010).

Artemisia arborescens L.: ("great mugwort," "arborescent mugwort") is physically in appearance capricious progenies (or amalgamation of species) with grey-green to silver leaves. It is indigenous to the varied dwellings of the Mediterranean area, where it exists as a shrub enlarging near about one meter in length. As reported by famous folklore, it was employed as anti-inflammatory medicine (Ballero et al. 2001).

Artemisia campestris L.: This is a perpetual subtle aromatic herb abundantly allocated in the south premises of Tunisia, frequently indicated as "tgouft". The leaves of this plant are broadly utilized as traditional remedies as a maceration formulation and satisfies its anti-inflammatory, antimicrobial anti-rheumatic as well as antivenin aspects (Hamed et al. 2014).

Artemisia douglasiana Besser.: In Argentina, it is substantially known as "California mugwort", which is fortuitously harvested in the Cuyo premises is consumed as a folk remedy confessed to receiving the prevalent name of "matico." The favored proper application of the decoction of leaves of "matico" is applicable in treating gastrointestinal problems and peptic ulcers (Ariza-Espinar and Bonzan 1992).

Artemisia dracunculus L.: ("tarragon") is a perennial herb, that has a detailed chronicle of consummation in culinary conventions. It also occupies a vast scope of health prosperity; hence this has been extensively employed as herbal remedy. Two well-reported cultivars (Russian and French) are employed broadly vary in ploidy extent, physical appearance chemistry. The photochemicals as well as medicinal ingredients, are meticulously described in the existed research, mainly emphasizing its essential oil constitution, which provides its characteristic flavor (Obolskiy et al. 2011).

Artemisia abrotanum L.: ("southernwood") was prescribed as an ancient remedy for diagnosing a range of ailments involving upper respiratory tract problems. Contemporarily, this perpetual plant is successfully applicable for culinary along with cosmetic prospects (Gruenwald 2000).

Artemisia scoparia Waldst. \& Kit.: ("Redstem wormwood") is a slightly perfumed annual herb that is distributed globally prevailing all over the globe, especially in southwest Asia regions as well as central European regions. The accomplishment of A. scoparia might be accredited to phytotoxins and essential oils, spare to another non-soaring secondary compounds. It has been entrenched that aerial pieces of $A$. scoparia manifested a soaring essential oil that possessed great therapeutic importance. It pertains to antibacterial, insecticidal, antiseptic, antipyretic, anticholesterolemic, vasodilatory, diuretic, cholagogue, and purgative characteristics; this is also applicable for the cure as well as recovery from gall bladder inflammation, jaundice along with hepatitis (Kooy and Sullivan 2013).

Artemisia spicigera C.: Koch, is called provincially in Turkey as "yavsani", is highly distributed in Eastern Central Anatolia areas, is conventionally employed for the cure of dermatological problems and ulcerative sores (Afshar et al. 2015).

Artemisia vulgaris L.: Frequently called "mugwort", is a perpetual weed found in North America, Europe-Asia, and Philippines, which is pertinent for its antihypertensive properties. It was also found to retain diverse characteristic medicinal aspects, namely anthelmintic, carminative, antispasmodic, and anti-inflammatory activities; as well as cure of onerous menstruation (dysmenorrhea) in the treatment of labor pain or miscarriage (MelguizoMelguizo et al. 2014).

\section{Conclusion}

Artemisia and its allied species have been traditionally and ethnopharmacologically used to treat many diseases such as 
diarrhoea, dysentery, cholera, diabetes, hypertension, inflammation, intestinal spasms, and liver diseases. Artemisia species contain diverse compounds whose principal chemical constituents are polyphenols and essential oils. The result showed a substantial conceivable quantitative and qualitative variation between essential oil contents of A. nilagirica and A. parviflora. These oils have been found to play an essential role in uncoupling of electron transport chain in a variety of bacterial species and can be used for food preservation and cosmetic preparations. They also contain coumarins, acetylenes, sesquiterpene, lactones, and a large number of phytoconstituents viz alcohols, phenols, flavonoids monoterpenes, and sesquiterpene derivatives. These species possess different pharmacological activities such as antineoplastic, antimalarial, insecticidal, antispasmodic, anti-inflammatory, antioxidant, antibacterial, antifungal, antiepileptic and analgesic properties. Acute studies showed that the plant to be nontoxic or low toxic, whereas chronic use of the plant causes toxicity. In this review, we have tried to abridge the pertinent findings, rational approaches, and innovative development regarding the ethnopharmacological activities of genus artemisia and novel therapeutic compounds that emerged out from this genus which are used to control and cure various types of common as well as lethal kinds of human diseases. It has been seen that $A$. апnиа is under clinical trial against COVID-19 disease, presently vast research is going against the treatment of this pandemic. If proved by researchers then chemical entities obtained from this genus will be cost effective, readily available, marvellous and will posssess persuasive therepeutic effect for combating against COVID-19. This review can be used for further research investigations as well as clinical purposes in the development of novel medicinally efficacious and safer plant derived drugs for curing several kinds of illnesses.

\section{Declarations}

Conflict of interest The authors declare that they have no conflict of interest.

\section{References}

Abad MJ, Bedoya LM, Apaza L, Bermejo P (2012) The Artemisia L. Genus, a review of bioactive essential oils. Molecules 17:25422566. https://doi.org/10.3390/molecules 17032542

Aberham A, Cicek SS, Schneider P, Stuppner H (2010) Analysis of sesquiterpene lactones, lignans, and flavonoids in wormwood (Artemisia absinthium L.) using high-performance liquid chromatography (HPLC)-mass spectrometry, reversed-phase HPLC, HPLC-solid phase extraction-nuclear magnetic resonance. J Agric Food Chem 58(20):10817-10823. https://doi.org/10.1021/ jf1022059

Abolaji AO, Eteng MU, Ebong PE, Brisibe EA (2013) A safety assessment of the antimalarial herb Artemisia annua during pregnancy in Wistar rats. Phytother Res 27(5):647-654. https:// doi.org/10.1002/ptr.4760

Abushwereb H, Tolba M (2016) Gastroprotective activity of Artemisia herba alba aqueous extract on aspirin-induced gastric lesions in Albino rats. J Pharm Appl Chem 2(3):141-145. https://doi.org/10.18576/jpac/020303

Adams JD, Garcia C, Garg G (2012) Mugwort (Artemisia vulgaris, Artemisia douglasiana, Artemisia argyi) in the treatment of menopause, premenstrual syndrome, dysmenorrhea and attention deficit hyperactivity disorder. Chin Med 3(3):116-123. https://doi.org/10.4236/cm.2012.33019

Addo-Mensah A, Garcia G, Maldonado IA, Anaya E, Cadena G, Lee LG (2015) Evaluation of antibacterial activity of Artemisia vulgaris extracts. Res J Med Plants 9(5):234-240. https://doi. org/10.3923/rjmp.2015.234.240

Adekenov SM (2016) Chemical modifications of arglabin and biological activity of its new derivatives. Fitoterapia 110:196-205. https://doi.org/10.1016/j.fitote.2015.11.018

Adekenov SM, Mukhametzhanov MN, Kagarlitskii AD, Kupriyanov AN (1982) Arglabin-a new sesquiterpene lactone from Artemisia glabella. Chem Nat Compd 18(5):623-624. https://doi. org/10.1007/BF00575063

Adjanohoun EJ, Ake-Assi L, Eyme J, Gassita JN, Goudote E, Gueho J, Ip FSL, Jackaria D, Kalachand SKK, Keita A, Koudogbo B, Landreau D, Owadall W, Soopramanien A (1983) Contributions aux Etudes ethnobotaniques et Floristiques a Maurice (Iles Maurice et Rodrigues). A.C.C.T., Paris, France

Afshar FH, Delazar A, Janneh O, Nazemiyeh H (2011) Evaluation of antimalarial, free-radical-scavenging insecticidal activities of Artemisia scoparia and Artemisia spicigera, Asteraceae. Revista Brasileira de Farmacognosia 21(6):986-990. https:// doi.org/10.1590/S0102-695X2011005000144

Afshar FH, Delazar A, Nazemiyeh H, Khodaie L, Moghaddam SB (2015) Phenolic derivatives of Artemisia spicigera C. Koch growing in Iran. Iran J Pharm Res 14(4):1241-1246

Agrawal B, Mehta A (2008) The antiasthmatic activity of Moringa oleifera Lam, a clinical study. Indian J Pharmacol 40(1):28-31. https://doi.org/10.4103/0253-7613.40486

Ahamad J, Mir SR, Amin S (2019) A pharmacognostic review on Artemisia absinthium. Int Res J Pharm 10(1):25-31. https:// doi.org/10.7897/2230-8407.10015

Ahameethunisa AR, Hopper W (2010) Antibacterial activity of Artemisia nilagirica leaf extracts against clinical phytopathogenic bacteria. BMC Complement Altern Med 10:6. https://doi.org/ 10.1186/1472-6882-10-6

Ahameethunisa AR, Hopper W (2012) In-vitro antimicrobial activity on clinical microbial strains and antioxidant properties of Artemisia parviflora. Ann Clin Microbiol Antimicrob 11:30. https://doi.org/10.1186/1476-0711-11-30

Ahangar N, Mirfetros S, Ebrahimzadeh MA (2011) Antidepressant activity of polyphenol fraction of Artemisia Absinthium L. Pharmacologyonline 1:825-832. https://doi.org/10.4314/ajb. v8i24.68818

Ahmed M, Azmat A, Khan S (2017) Acute hypotensive diuretic activities of Berberis vulgaris root bark aqueous extract in normal rats. Braz J Pharm Sci 53(4):e17077. https://doi.org/ 10.1590/s2175-97902017000417077

Ahuja J, Suresh J, Paramakrishnan N, Mruthunjaya K, Naganhini MN (2011) An ethnomedical, phytochemical and pharmacological profile of Artemisia parviflora Roxb. J Essent Oil-Bear Plants 14(6):647-657. https://doi.org/10.1080/0972060X.2011. 10643985

Ahuja A, Yi Y, Kim M, Cho JY (2018) Ethnopharmacological properties of Artemisia asiatica: a comprehensive review. J Ethnopharmacol 220:117-128. https://doi.org/10.1016/j.jep. 2018.03.032 
Akkol EK, Dereli FTG, Ilhan M (2019) Assessment of antidepressant effect of the aerial parts of Micromeria myrtifolia Boiss. \& Hohen on mice. Molecules 24(10):1869. https://doi.org/10.3390/ molecules 24101869

Albayrak S, Aksoy A, Sagdic O (2010) Phenolic compounds and antioxidant and antimicrobial properties of Helichrysum species collected from eastern Anatolia, Turkey. Turk J Biol 34:463-473. https://doi.org/10.3906/biy-0901-4

Alizadeh M, Aghaei M, Saadatian M, Sharifian I (2012) Chemical composition of essential oil of Artemisia vulgaris from West Azerbaijan, Iran. Electron J Environ Agricult Food Chem 11(5):493-496

Almeida ER, Silva AR, Aragao-Neto AC, Soares PH (2013) Anticonvulsant and anxiolytic assessment of leaves from Artemisia vulgaris L. in mice. J Med Plant Res 7(45):3325-3331. https://doi. org/10.5897/JMPR 12.873

Amat N, Upur H, Blazekovic B (2010) In-vivo hepatoprotective activity of the aqueous extract of Artemisia absinthium L. against chemically immunologically induced liver injuries in mice. J Ethnopharmacol 131:478-484. https://doi.org/10.1016/j.jep. 2010.07.023

Amirmohammadi M, Khajoenia S, Bahmani M, Kopaei MR, Eftekhari Z, Qorbani M (2014) In-vivo evaluation of antiparasitic effects of Artemisia abrotanum and Salvia officinalis extracts on Syphacia obvelata, Aspiculoris tetrapetra and Hymenolepis nana parasites. Asian Pac J Trop Dis 4(1):S250-S254. https://doi.org/10.1016/ S2222-1808(14)60449-7

Anosike CA, Obidoa O, Ezeanyika LU (2012) Membrane stabilization as a mechanism of the anti-inflammatory activity of methanol extract of garden egg (Solanum aethiopicum). DARU J Pharm Sci 20(1):76. https://doi.org/10.1186/2008-2231-20-76

Arab H, Rahbari S, Rassouli A, Moslemi MH, Khosravirad FDA (2006) Determination of artemisinin in Artemisia sieberi and anticoccidial effect of the plant extract in broiler chickens. Trop Anim Health Prod 38(6):497-503. https://doi.org/10.1007/ s11250-006-4390-8

Ariza-Espinar L, Bonzan N (1992) El matico de la region de Cuyo (Argentina). Acta Farm Bonaer 11:39-145

Arokiyaraj S, Sripriya N, Bhagya R, Radhika B, Prameela L, Udayaprakash NK (2012) Phytochemical screening, antibacterial and free radical scavenging effects of Artemisia nilagirica, Mimosa pudica, Clerodendrum siphonanthus - an in-vitro study. Asia Pac J Trop Biomed 2(2):S601-S604. https://doi.org/10. 1016/S2221-1691(12)60281-0

Aslam M (2016) Tail suspension test to evaluate the antidepressant activity of experimental drugs. Bangladesh J Pharmacol 11(2):292-294. https://doi.org/10.3329/bjp.v11i2.26517

Ataei AA, Delnavaz HB (2019) Terpenoid compounds and anti-hemozoin and anti-ciliates protozians effects of Artemisia annиa L. and Chenopodium botrys L. J Med Plants 18(71):49-66. https:// doi.org/10.29252/jmp.3.71.49

Auddy B, Ferreira M, Blasina F, Lafon L, Arredondo F, Dajas F (2003) Screening of antioxidant activity of three Indian medicinal plants, traditionally used for the management of neurodegenerative diseases. J Ethnopharmacol 84:131-138. https://doi.org/10. 1016/s0378-8741(02)00322-7

Avula B, Wang YH, Smilie TJ, Mebusela W, Vincent L, Weitz F, Khan IA (2009) Quantitative determination of flavonoids by column high-performance liquid chromatography with mass spectrometry and ultraviolet absorption detection in Artemisia afar and comparative studies with various species of Artemisia plants. J AOAC Int 92:633-644

Aziz MA, Khan AH, Ullah H, Adnan M, Hashem A, Abd_Allah EF (2018) Traditional phytomedicines for gynecological problems used by tribal communities of Mohm Agency near the
Pak-Afghan border area. Braz J Pharmacogn 28:503-511. https:// doi.org/10.1016/j.bjp.2018.05.003

Baananou S, Bouftria I, Mahmoud A, Boukef K, Marongiu B (2013) Antiulcerogenic and antibacterial activities of Apium graveolens essential oil extract. Nat Prod Res 27:1075-1083. https://doi.org/ 10.1080/14786419.2012.717284

Badoni R, Semwal DK, Rawat U (2010) Composition variation in essential oils of Artemisia nilagirica and Artemisia capillaris, growing in India. J Appl Nat Sci 2(1):30-33. https://doi.org/10. 31018/jans.v2i1.90

Bahmani M, Rafieian-Kopaei M, Hassanzadazar H, Saki K (2014) A review on most important herbal and synthetic antihelmintic drugs. Asia Pac J Trop Med 7(1):S29-S33. https://doi.org/10. 1016/S1995-7645(14)60200-5

Balasubramani S, Sabapathi G, Moola AK, Solomon RV, Venuvanalingam P, Diana RKB (2018) Evaluation of the leaf essential oil from Artemisia vulgaris and its larvicidal repellent activity against dengue fever vector Aedes aegypti-an experimental and molecular docking investigation. ACS Omega 3(11):1565715665. https://doi.org/10.1021/acsomega.8b01597

Ballero M, Poli F, Sacchetti G, Loi MC (2001) Ethnobotanical research on the territory of Fluminimaggiore (southwestern Sardinia). Fitoterapia 72:788-801. https://doi.org/10.1016/s0367-326x(01) 00334-3

Balunas MJ, Kinghorn AD (2005) Drug discovery from medicinal plants. Life Sci 78(5):431-441. https://doi.org/10.1016/j.lfs. 2005.09.012

Bamoniri A, Mirjalili BBF, Mazoochi A, Batooli H (2010) Chemical composition of Artemisia vulgaris L. from Kashan area isolated by nanoscale injection. Iran J Org Chem 2(4):533-536

Bamunuarachchi GS, Ratnasooriya WD, Premakumara S, Udagama PV (2013) Antimalarial properties of Artemisia vulgaris L. ethanolic leaf extract in a Plasmodium berghei murine malaria model. Vector Borne Dis 50:278-284

Banerji A, Luthriya DL, Kokate SD (1990) Toxicity of capillin, the insecticidal principle of Artemisia nilagirica Clarke. Indian $\mathrm{J}$ Exp Biol 28:588-589. https://doi.org/10.1016/j.sjbs.2018.09.005

Bansal J, Kumar N, Malviya R, Sharma PK (2014) Hepatoprotective models various natural product used in hepatoprotective agents, a review. Pharmacogn Commun 4(3):2-30. https://doi.org/10. 5530/pc.2014.3.2

Barradell LB, Fitton A (1995) Artesunate: a review of its pharmacology and therapeutic efficacy in the treatment of malaria. Drugs 50:714-741. https://doi.org/10.2165/00003495-19955 0040-00009

Basco LK, Le-Bras J (1993) In-vitro activity of artemisinin derivatives against African isolates and clones of Plasmodium falciparum. Am J Trop Med Hyg 49(3):301-307. https://doi.org/10.4269/ ajtmh.1993.49.301

Beigh YA, Ganai AM (2017) Potential of Wormwood (Artemisia absinthium Linn.) herb for use as additive in livestock feeding: A review. Pharma Innov 6(8):176-187

Bereksi MS, Hassaine H, Bekhechi C, Abdelouahid DE (2018) Evaluation of antibacterial activity of some medicinal plants extracts commonly used in Algerian traditional medicine against some pathogenic bacteria. Pharmacogn J 10(3):507-512. https://doi. org/10.5530/pj.2018.3.83

Beshay EVN (2018) Therapeutic efficacy of Artemisia absinthium against Hymenolepis nana, in-vitro in-vivo studies in comparison with the anthelmintic praziquantel. J Helminthol 92(3):298-308. https://doi.org/10.1017/S0022149X17000529

Bhat JA, Kumar M, Bussmann RW (2013) Ecological status traditional knowledge of medicinal plants in Kedarnath Wildlife Sanctuary of Garhwal Himalaya, India. J Ethnobiol Ethnomed 9:1. https:// doi.org/10.1186/1746-4269-9-1 
Bhatt LR, Lee JS, Baek SH (2007) Evaluation of the antioxidant activity of essential oil from Artemisia vulgaris. J Physiol Pathol Korean Med 21(2):528-531. https://ocean.kisti.re.kr/downfile/ volume/ksomp/DRSRDH/2007/v21n2/DRSRDH_2007_v21n2_ 528.pdf

Bhatt I, Rawat S, Rawal R (2013) Antioxidants in medicinal plants. Biotechnol Med Plants J Physiol Pathol Korean Med. https://doi. org/10.1007/978-3-642-29974-2_13

Biesen CM (2010) The rise to prominence of Artemisia annua L. -the transformation of a Chinese plant to a global pharmaceutical. Afr Sociol Rev/Revue Africaine de Sociologie 14(2):24-46. https:// doi.org/10.4314/asr.v14i2.70234

Blagojevic P, Radulovic N, Palic R, Stojanovic GJ (2006) Chemical composition of the essential oils of Serbian wild-growing Artemisia absinthium and Artemisia vulgaris. J Agric Food Chem 54(13):4780-4789. https://doi.org/10.1021/jf060123o

Blois MS (1958) Antioxidant determinations by the use of a stable free radical. Nature 181:1199-1200. https://doi.org/10.1038/ $1811199 \mathrm{a} 0$

Boareto AC, Muller JC, Bufalo AC, Botelho GGK, de Araujo SL, Foglio MA, de Morais RN, Dalsenter PR (2008) Toxicity of artemisinin [Artemisia аппиа L.] in two different periods of pregnancy in Wistar rats. Reprod Toxicol 25(2):239-246. https://doi. org/10.1016/j.reprotox.2007.11.003

Bora KS, Sharma A (2011) The Genus Artemisia, a comprehensive review. Pharm Biol 49:101-109. https://doi.org/10.3109/13880 209.2010.497815

Bottex-Gauthier C, Vidal D, Picot F, Potier P, Menichini F, Appendino G (1993) In-vitro biological activities of arglabin, a sesquiterpene lactone from the Chinese herb Artemisia myriantha Wall. (Asteraceae). Biotechnol Ther 4(1-2):77-98

Brandao MG, Krettli AU, Soares LSR (1997) Antimalarial activity of extract fractions from Bidens Pilosa other Bidens species (Asteraceae) correlated with the presence of acetylene flavonoids compounds. J Ethnopharmacol 57:131-138. https://doi.org/10.1016/ s0378-8741(97)00060-3

Braquet P, Etienne A, Mencia-Huerta JM, Clostre F (1988) Effects of the specific platelet-activating factor antagonists, BN 52021 and BN 52063, on various experimental gastrointestinal ulcerations. Eur J Pharmacol 150:269-276. https://doi.org/10.1016/00142999(88)90007-6

Brenda SW, Bansal A, Moriarity DM, Takku S, Setzer WN (2007) Cytotoxic leaf essential oils from Neotropical Lauraceae: synergistic effect of essential oil components. Nat Prod Commun 2:1241-1244. https://doi.org/10.1177/1934578X0700201210

Brown GD (2010) The biosynthesis of artemisinin (Qinghaosu) the phytochemistry of Artemisia annua L. (Qinghao). Molecules 15(11):7603-7698. https://doi.org/10.3390/molecules15117603

Bum EN, Schmutz M, Meyer C, Rakotonirina A, Rakotonirina SV, Olpe HR, Herrling P (2001) Anticonvulsant properties of the methanolic extract of Cyprus articulatus (Cyperaceae). J Ethnopharmacol 76(2):145-150. https://doi.org/10.1016/S03788741(01)00192-1

Burg RW, Miller BM, Baker EE, Birnbaum J, Currie SA, Hartman R, Kong Y, Monaghan RL, Olson G, Putter I, Tu-nac JB, Hallick H, Stapley EO, Ruiko O, Omura S (1979) Avermectins, a new family of potent anthelmintic agents: producing organism and fermentation. Antimicrob Agents Chemother 15(3):361-367. https://doi.org/10.1128/aac.15.3.361

Campbell WC (2012) History of avermectin and ivermectin, with notes on the history of other macrocyclic lactone antiparasitic agents. Curr Pharm Biotechnol 13(6):853-865. https://doi.org/10.2174/ 138920112800399095

Campbell WC, Blair LS, Lotti VJ (1979) Efficacy of avermectins against Trichinella spiralis in mice. J Helminthol 53(3):254-256. https://doi.org/10.1017/s0022149x00006052
Campbell WC, Fisher MH, Stapley EO, Albers-Schonberg G, Jacob TA (1983) Ivermectin: a potent new antiparasitic agent. Science 221(4613):823-828. https://doi.org/10.1126/science. 6308762

Carlton JM, Angiuoli SV, Suh BB, Kooij TW, Pertea M, Silva JC (2002) Genome sequence comparative analysis of the model rodent malaria parasite Plasmodium yoelii. Nature 419:512-519. https://doi.org/10.1038/nature01099

Carter R, Mendis KN (2002) Evolutionary historical aspects of the burden of malaria. Clin Microbiol Rev 15(4):564-594. https:// doi.org/10.1128/CMR.15.4.564-594.2002

Cazzoletti L, Marcon A, Corsico A, Janson C, Jarvis D (2010) Asthma severity according to Global initiative for Asthmatics determinants, an international study. Int Arch Allergy Immunol 151(1):70-79. https://doi.org/10.1159/000232572

Chabala JC, Mrozik H, Tolman RL, Eskola P, Lusi A, Peterson LH, Woods MF, Fisher MH, Campbell WC, Egerton JR, Ostlind DA (1980) Ivermectin, a new broad-spectrum antiparasitic agent. J Med Chem 23(10):1134-1136. https://doi.org/10.1021/jm001 $84 \mathrm{a} 014$

Chakraborty A, Brantner AH (1999) Antibacterial steroid alkaloid from the stem bark of Holarrhena pubescens. villosum leaves. J Ethnopharmacol 68:339-344. https://doi.org/10.1016/s03788741(99)00119-1

Cheng VCC, Lau SKP, Woo PCY, Yuen KY (2007) Severe acute respiratory syndrome coronavirus as an agent of emerging and reemerging infection. Clin Microbiol Rev 20(4):660-694. https:// doi.org/10.1128/CMR.00023-07

Cho JY, Park KH, Hwang DY, Chanmuang S, Jaiswal L (2015) Antihypertensive effects of Artemisia scoparia Waldst in spontaneously hypertensive rats and identification of angiotensin I converting enzyme inhibitors. Molecules 20(11):19789-19804. https://doi. org/10.3390/molecules201119657

Choi WS, Jang DY, Nam SW, Park BS, Lee HS, Lee SE (2012) Antiulcerogenic activity of scoparone on $\mathrm{HCl} /$ ethanol-induced gastritis in rats. J Korean Soc Appl Biol 55:159-163. https://doi.org/10. 1007/s13765-012-1023-y

Choi E, Park H, Lee J, Kim G (2013a) Anticancer, antiobesity, and anti-inflammatory activity of Artemisia species in-vitro. J Tradit Chin Med 33(1):92-97. https://doi.org/10.1016/s0254-6272(13) 60107-7

Choi M, Han J, Kim H (2013b) Aqueous extract of Artemisia capillaris exerts hepatoprotective action in alcohol-pyrazole-fed rat model. J Ethnopharmacol 147(3):662-670. https://doi.org/10.1016/j.jep. 2013.03.065

Chou C (1998) The anti-inflammatory effect of an extract of Tripterygium wilfordii Hook $\mathrm{F}$ on adjuvant-induced Paw oedema in rats and inflammatory mediators release. Phytother Res 11(2):152154. https://doi.org/10.1002/(SICI)1099-1573(199703)11:2\% 3c152::AID-PTR45\%3e3.0.CO;2-L

Chowdhury N, Laskar S, Chra G (2008) Mosquito larvicidal antimicrobial activity of protein of Solanum villosum leaves. BMC Complement Altern Med 8:62. https://doi.org/10.1186/ $1472-6882-8-62$

Classen W, Altmann B, Gretener P, Souppart C, Skelton-Stroud P, Krinke G (1999) Differential effects of orally versus parenterally administered qinghaosu derivative artemether in dogs. Exp Toxicol Pathol 51(6):507-516. https://doi.org/10.1016/S09402993(99)80128-6

Coman C, Rugina OD, Socaciu C (2012) Plants and natural compounds with antidiabetic action. Not Bot Hort Agrobot Cluj-Napoca 40(1):314-325. https://doi.org/10.15835/nbha4017205

Costa M, Fina RD, Valentino MR, Rustaiyan A, Dugo P, Dugo G, Mondello L (2009) An investigation on the volatile composition of some Artemisia species from Iran. Flavour Fragr J 24(2):75-82. https://doi.org/10.1002/ffj.1919 
Czechowski T, Rinaldi MA, Famodimu MT, Veelen MV, Larson TR, Winzer T, Rathbone DA, Harvey D, Horrocks P, Graham IA (2019) Flavonoid versus artemisinin anti-malarial activity in Artemisia аппиа whole-leaf extracts. Front Plant Sci 10:984. https://doi.org/10.3389/fpls.2019.00984

Dabe NE, Kefala AT (2017) Antidiabetic effects of artemisia species: a systematic review. Anc Sci Life 36(4):175-181. https://doi.org/ 10.4103/asl.ASL_87_17

Darvishpor S, Hosseini A, Davoodi A, Salehifar E, Akbari J, Azadbakht M (2018) A review on medicinal plants used for nausea and vomiting in Persian medicine. Glob J Med Res 18(1):29-45. https://medicalresearchjournal.org/index.php/GJMR/article/ view/1496

de Ridder S, van der Kooy F, Verpoorte R (2008) Artemisia annua as a self-reliant treatment for malaria in developing countries. J Ethnopharmacol 120(3):302-314. https://doi.org/10.1016/j.jep. 2008.09.017

de Souza EPBSS, Faria RX, Rocha LM (2016) Clinical trials studies of plant extracts with anti-inflammatory activity. J Appl Pharm Sci 6(12):224-232. https://doi.org/10.7324/JAPS.2016.601233

Delabays N, Simonnet X, Gaudin M (2001) The genetics of artemisinin content in Artemisia annua L. the breeding of high yielding cultivars. Curr Med Chem 8(15):1795-1801. https://doi.org/10.2174/ 0929867013371635

Devmurari VP, Jivani NP (2010) Anticancer evaluation of Artemisia nilagirica. Int J Pharm Tech Res 2(2):1603-1608

Devmurari VP, Pandey S, Goyani MB, Jivani NP (2010) Phytochemical screening of ethanolic extract of Artemisia nilagirica. Int J Chem Sci 8(4):2099-2104

Dhanapal ACTA, Ming TW, Aung HP, Hao SJ (2016) Preliminary screening of Artemisia argyi for antioxidant potentials. Int $\mathbf{J}$ Pharmacogn Phytochem Res 8(2):347-355

Dib I, Alaouri-faris F (2019) Artemisia campestris L.: review on taxonomical aspects, cytogeography, biological activities, and bioactive compounds. Biomed Pharmacother 109:1884-1906. https:// doi.org/10.1016/j.biopha.2018.10.149

Dorsch W, Ettl M, Hein G, Scheftner P, Weber J, Bayer T, Wagner H (1987) Anti-asthmatic effects of onions. Inhibition of plateletactivating factor-induced bronchial obstruction by onion oils. Int Arch Allergy Appl Immunol 82:535-536

Drazen JM (1997) Pharmacology of leukotriene receptor antagonists and 5-lipoxygenase inhibitors in the management of asthma. Pharmacotherapy 17(1 Pt 2):22S-30S. https://pubmed.ncbi.nlm. nih.gov/9017785/

Du JH, Zhang HD, Ma ZJ, Ji KM (2010) Artesunate induces oncosislike cell death in vitro and has antitumor activity against pancreatic cancer xenografts in-vivo. Cancer Chemother Pharmacol 65:895-902. https://doi.org/10.1007/s00280-009-1095-5

Dyson AJ, Mackay AD (1980) Ketotifen in adult asthma. BMJ 280(6211):360-361. https://doi.org/10.1136/bmj.280.6211.360

Efferth T (2015) Artemisinin-second career as anticancer drug? World J Tradit Chin Med 1(4):2-25. https://doi.org/10.15806/j.issn. 2311-8571.2015.0036

Efferth T (2017) From ancient herb to modern drug, Artemisia annua and artemisinin for cancer therapy. Semin Cancer Biol 46:65-83. https://doi.org/10.1016/j.semcancer.2017.02.009

Elhassan IA, Ibrahim NY, Mahmoud OM, Salam AM (2013) Antitubercular activity of essential oils from Cymbopogon citratus, C. nervatus, C. proximus. J Pharmacogn Phytochem 5(1):19-23

El-Tantawy WH (2015) Biochemical effects, hypolipidemic antiinflammatory activities of Artemisia vulgaris extract in hypercholesterolemic rats. J Clin Biochem Nutr 57(1):33-38. https:// doi.org/10.3164/jcbn.14-141

Emami SA, Vahdati-Mashhadian N, Vosough R, Oghazian MB (2009) The anticancer activity of five species of Artemisia on Hep2HepG2 cell lines. Pharmacol Online 3:327-339
Erdogrul OT (2002) Antibacterial activities of some plant extracts used in folk medicine. Pharm Biol 40(4):269-273. https://doi.org/10. 1076/phbi.40.4.269.8474

Erel SB, Reznicek G, Senol SG, Yavasogulu NUK, Konyalioglu S, Zeybek AU (2012) Antimicrobial and antioxidant properties of Artemisia L. species from western Anatolia. Turk J Biol 36:7584. https://doi.org/10.3906/biy-0912-27

Esen M, Grassme H, Riethmuller J, Riehle A, Fassbender K, Gulbins E (2001) Invasion of human epithelial cells by Pseudomonas aeruginosa involves Src-like tyrosine kinase p60Srcp59Fyn. Infect Immun 69(1):281-287. https://doi.org/10.1128/IAI.69.1. 281-287.2001

Esmaeili F, Sepehri G, Kashanian GRM, Khaksari M (2009) The effect of acute administration of Artemisia persia extracts on arterial blood pressure heart rate in rats. Am J Appl Sci 6(5):843-847. https://doi.org/10.3844/ajas.2009.843.847

Faizei F, Maghsood AH, Parin F (2015) Antiprotoscolices effect of methanolic extract of Zingiber officinale, Artemisia aucheri and Eucalyptus globulus against Echinococcus granulosus invitro. Iran J Pharmacol Ther 14(1):7-11

Fakhoury M, Negrulj R, Mooranian A, Al-Salami H (2014) Inflammatory bowel disease: clinical aspects and treatments. J Inflamm Res 4(7):113-120. https://doi.org/10.2147/JIR.S65979

Fakim AG (1990) Medicinal plants of Mauritius. Int J Crude Drug Res 28:297-308. https://doi.org/10.3109/13880209009082837

Farahani ZB, Mirzaie A, Ashrafi F, Hesari MR, Chitgar A, Noorbazargan H, Rahimi A (2017) Phytochemical composition and biological activities of Artemisia quettensis Podlech ethanolic extract. Nat Prod Resour 31(21):2554-2558. https://doi.org/10.1080/ 14786419.2017.1318385

Formisano C, Rigano D, Russo A (2012) Phytochemical profile and apoptotic activity of Onopordum cynarocephalum. Planta Med 78(15):1651-1660. https://doi.org/10.1055/s-0032-1315259

Geller C, Varbanov M, Duval RE (2012) Human coronaviruses: insights into environmental resistance and its influence on the development of new antiseptic strategies. Viruses 4:3044-3068. https://doi.org/10.3390/v4113044

Ghazanfar K, Ganai BA, Akbar S, Mubashir K, Dar SA, Dar MY, Tantry MA (2014) Antidiabetic activity of Artemisia amygdalina Decne in streptozotocin-induced diabetic rats. Biomed Res Int 2:185676. https://doi.org/10.1155/2014/185676

Ghisalberti EL, Pennacchio M, Alexer E (1998) Survey of secondary plant metabolites with cardiovascular activity. Pharm Biol 36(4):237-279. https://doi.org/10.1076/phbi.36.4.237.4583

Ghisan R, Thamaraichelvan A, Baburaj K (1991) Anti-inflammatory action of Lannnea coromelica by HRBC membrane stabilization. Fitoterapia 62(1):81-83

Gilani AH, Janbaz KH (1993) Protective effect of Artemisia scoparia extract against acetaminophen-induced hepatotoxicity. Gen Pharmacol 24(6):1455-1458. https://doi.org/10.1016/0306-3623(93) 90434-y

Gilani AH, Yaeesh S, Jamal Q, Ghayur MN (2005) Hepatoprotective activity of aqueous-methanol extract of Artemisia vulgaris. Phytother Res 19:170-172. https://doi.org/10.1002/ptr.1632

Goel R, Singh V, Kumari R, Kumari R, Srivastava S, Mallavarapu GR, Goel D, Kumar S (2019) Artemisia (Asteraceae) essential oils: compositional variation and mechanisms of its origin, biosynthesis of constituents, correspondence between biological activities and ethnomedicinal usage and repurposement prospects. Proc Indian Natl Sci Acad 85(4):723-790. https://doi.org/10.16943/ ptinsa/2019/49644

Gordanian B, Behbahani M, Carapetian J, Fazilati M (2014) In-vitro evaluation of cytotoxic activity of flower, leaf, stem and root extracts of five artemisia species. Res Pharm Sci 9(2):91-96

Govindaraj SP, Kumari BDR (2013) Composition and larvicidal activity of Artemisia vulgaris L. stem essential oil against 
Aedes aegypti. Jordan J Biol Sci 6(1):11-16. https://doi.org/ $10.12816 / 0000252$

Griselda H, Horacio MG, Jorge E (2016) Argentinean's plants with interest in ethnomedicine as wormers. Int J Pharmacol Phytochem Ethnomed 5:1-17. https://doi.org/10.18052/www.scipr ess.com/IJPPE.5.1

Gruenwald J (2000) PDR for herbal medicines, 2nd edn. Medical Economics, Montvale

Gruenwald J, Brendler T, Jaenicke C (2008) PDR of herbal medicine, 4th edn. Thomson Healthcare, Florence, pp 91-593

Gul MZ, Ahmad F, Kondapi AK, Qureshi IA, Ghazi IA (2013) Antioxidant and antiproliferative activities of Abrus precatorius leaf extracts-an in-vitro study. BMC Complement Altern Med 13:53. https://doi.org/10.1186/1472-6882-13-53

Gupta RC, Himshikha RPK, Kumar P, Singhal VK (2010) First report of structural heterozygosity in Artemisia parviflora (Asteraceae) from Parvati Valley in Kullu district (Himachal Pradesh, India). Bot Serbica 34(1):63-66.

Gupta RC, Goyal H, Singh V (2014) Cytology of the genus Artemisia (Anthemidae, Asteraceae) in the Western Himalayas. Biologia 69:1134-1141. https://doi.org/10.2478/s11756-014-0413-5

Gurib-Fakim A, Gueho J, Sewraj MD, Dulloo E (1993) Medical ethnobotany of some weeds of Mauritius Rodrigues. J Ethnopharmacol 9:175-185. https://doi.org/10.1016/0378-8741(93) 90034-3

Gurib-Fakim A, Guho J, Sewraj MD (1996a) Plantes Medicinales de Maurice, Editions de l'Ocean Indien, Stanley, Rose Hill. Mauritius, pp 1-498

Gurib-Fakim A, Gueho J, Sewraj MD, Dulloo E (1996b) Medicinal plants of Rodrigues. Int J Pharmacogn 34:2-14. https://doi.org/ 10.1076/phbi.34.1.2.13177

Gurib-Fakim A, Gueho J, Sewraj-Bissoondoyal M (1997) The medicinal plants of Mauritius-Part 1. Int J Pharmacogn 35(4):237254. https://doi.org/10.1076/phbi.35.4.237.13313

Ha H, Lee H, Seo CS, Lim H, Lee JK (2014) Artemisia capillaris inhibits atopic dermatitis-like skin lesions in Dermatophagoides farinae-sensitized Nc/Nga mice. BMC Complement Altern Med 14:100. https://doi.org/10.1186/1472-6882-14-100

Haider F, Dwivedi PD, Naqvi AA, Bagchi GD (2003) Essential oil composition of Artemisia vulgaris harvested at different growth periods under Indo-Gangetic plain conditions. J Essent Oil Res 15(6):376-378. https://doi.org/10.1080/10412905.2003.9698615

Haider F, Kumar N, Naqvi AA, Bagchi GD (2010) Oil constituents of Artemisia nilagirica var. septentrionalis is growing at different altitudes. Nat Prod Commun 5:1959-1960

Halliwell B, Gutteridges JM (1984) Oxygen toxicity, oxygen radicals, transition metals and disease. Biochem J 219(1):1-14. https:// doi.org/10.1042/bj2190001

Hamed BN, Serria HT, Lobna M, Khaled Z (2014) Aqueous leaf extracts of Artemisia campestris inhibition of the scorpion venom induced hypertension. J Med Plant Res 8(13):538-542. https://doi.org/10.5897/JMPR12.954

Han KH, Jeon YJ, Athukorala Y (2006) A water extract of Artemisia capillaris prevents 2,2'-azobis (2-amidinopropane) dihydrochloride-induced liver damage in rats. J Med Food 9(3):342-347. https://doi.org/10.1089/jmf.2006.9.342

Han G, Shin H, Seong S, Kim S (2018) Systematic review of case reports about Korean medicine for lung cancer. J Korean Med 39(4):136-157. https://doi.org/10.13048/jkm.18041

Haq S, Grondin J, Banskota S, Khan WI (2019) Autophagy: roles in intestinal mucosal homeostasis and inflammation. J Biomed Sci 26:19. https://doi.org/10.1186/s12929-019-0512-2

Haq FU, Roman M, Ahmad K, Rahman SU, Shah SMA, Suleman N, Ullah S, Ahmad I, Ullah W (2020) Artemisia annua: trials are needed for COVID-19. Phytother Res. https://doi.org/10.1002/ ptr.6733
Hassan AM, Ashton M, Kihamia CM, Mtey GJ, Bjorkman A (1996) Multiple-dose pharmacokinetics of oral artemisinin and comparison of its efficacy with that of oral artesunate in falciparum malaria patients. Trans R Soc Trop Med Hyg 90(1):61-65. https://doi.org/10.1016/s0035-9203(96)90480-0

Hijazi AM, Salhab AS (2010) Effects of Artemisia monosperma ethanolic leaves extract on implantation, mid-term abortion and parturition of pregnant rats. J Ethnopharmacol 128(2):446-451. https://doi.org/10.1016/j.jep.2010.01.030

Hiremath SK, Kolume DG, Muddapur UM (2011) Antimicrobial activity of Artemisia vulgaris Linn. (Damanaka). Int J Res Ayurveda Pharm 2(6):1674-1675. http://www.ijrap.net

Hojageldiyev T, Bolmammedov Y, Gurbanaliyev S (2019) Antimycobacterial activity of ethanolic extract of Artemisia absinthium L. World Sci News 119:224-230

Honmore V, Khare A, Zanwar AA (2014) Artemisia pallens alleviates acetaminophen-induced toxicity via modulation of endogenous biomarkers. Pharm Biol 53(4):571-581. https://doi.org/10.3109/ 13880209.2014.934382

Hossain MM, Ahamed SK, Dewan SMR, Hassan MM (2014) In-vivo antipyretic, antiemetic, in-vitro membrane stabilization, antimicrobial and cytotoxic activities of different extracts from Spilanthes paniculate leaves. Biol Res 47:45. https://doi.org/10.1186/ 0717-6287-47-45

Huntley A, Ernst E (2000) Herbal medicines for asthma: a systematic review. Thorax 55:925-929. https://doi.org/10.1136/thorax.55. 11.925

Hussain AI, Anwar F, Sherazi STH, Przybylski R (2008) Chemical composition, antioxidant and antimicrobial activities of basil (Ocimum basilicum) essential oils depends on seasonal variations. Food Chem 108:986-995. https://doi.org/10.1016/j.foodc hem.2007.12.010

Hussain A, Hayat MQ, Sahreen S, Ain Q, Bokhari SAI (2017) Pharmacological promises of genus Artemisia (Asteraceae): a review. B Life Environ Sci 54(4):265-287

Iqbal S, Younas U, Chan KW, Zia-Ul-Haq M, Ismail M (2012) Chemical composition of Artemisia апnиa L. leaves and antioxidant potential of extracts as a function of extraction solvents. Molecules 17(5):6020-6032. https://doi.org/10.3390/molecules1 7056020

Irum S, Ahmed H, Mirzak BK, Donskow-Lysoniewska K, Muhammad A (2017) In-vitro and in-vivo anthelmintic activity of extracts from Artemisia parviflora and Artemisia sieversiana. Helminthologia 54(3):218-224. https://doi.org/10.1515/helm-2017-0028

Iwueke AV, Nwodo OF, Okoli CO (2006) Evaluation of anti-inflammatory and analgesic activities of Vitex doniana leaves. Afr J Biotechnol 5(20):1929-1935. https://doi.org/10.5897/AJB2006. 000-5086

Jahani R, Khaledyan D, Jahani A, Jamshidi E (2019) Evaluation comparison of the antidepressant-like activity of Artemisia dracunculus and Stachys lavulifolia ethanolic extracts: an in-vivo study. Res Pharm Sci 14(6):544-553. https://doi.org/10.4103/ 1735-5362.272563

Jain DC, Bhakuni RS, Sharma RP, Kahol AP, Dutta GP, Kumar S (2000) Domestication of Artemisia annua plant and development of new antimalarial drug arteether in India. J Sci Ind Res 59(1):1-11

Jasinskas A, Simonaviciote R, Siaudinis G, Liaudanskiene I, Antanaitis S, Apak M, Olt J (2014) The assessment of common mugwort (Artemisia vulgaris L.) and cup plant (Silphium prefoliatum L.) productivity and technological preparation for solid biofuel. Zemdirb-Agric 101(1):19-26. https://doi.org/10.13080/z-a.2014. 101.003

Jassim SAA, Naji MA (2003) Novel antiviral agents: a medicinal plant perspective. J Appl Microbiol 95(3):412-427. https://doi.org/10. 1046/j.1365-2672.2003.02026.x 
Jerkovic I, Mastelic J, Milos M, Juteau F, Masotti V, Viano J (2003) Chemical variability of Artemisia vulgaris $\mathrm{L}$. essential oils originated from the Mediterranean area of France and Croatia. Flavour Fragr J 18(5):436-440. https://doi.org/10.1002/ffj.1246

Jiao P, Moore B, Hong M, Clevel S, Chu M (2016) Hepatoprotective activity of herbal composition SAL, a standardize blend comprised of Schisra chinensis, Artemisia capillaris, and Aloe barbadensis. J Nutr Metab. https://doi.org/10.1155/2016/3530971

Jimenez-Arellanes MA, Gutierrez-Rebolledo G, Rojas-Tome S (2014) Medicinal plants, an important reserve of antimycobacterial and antitubercular drugs: an update. J Infect Dis Ther 2:185. https:// doi.org/10.4172/2332-0877.1000185

Joshi RK, Satyal P, Setzer WN (2016) Himalayan aromatic medicinal plants: a review of their ethnopharmacology, volatile phytochemistry,and biological activities. Medicines (Basel) 3(1):6. https://doi.org/10.3390/medicines3010006

Judzentiene A, Buzelyte J (2006) Chemical composition of essential oils of Artemisia vulgaris L. (Mugwort) from plants grown in North Lithuania. CHEMIJA 17(1):12-15. https://www.resea rchgate.net/publication/291160304

Juteau F, Masotti V, Bessiere JM, Dherbomez M, Viano J (2002) Antibacterial and antioxidant activities of Artemisia annua essential oil. Fitoterapia 73(6):532-535. https://doi.org/10.1016/S0367326X(02)00175-2

Jyoti MA, Nam KW, Jang WS, Kim YH, Kim SK, Lee BE, Song HY (2016) Antimycobacterial activity of methanolic plant extract of Artemisia capillaris containing ursolic acid and hydroquinone against Mycobacterium tuberculosis. J Infect Chemother 22(4):200-208. https://doi.org/10.1016/j.jiac.2015.11.014

Kabra SK, Pandey RM, Singh R, Seth V (2000) Ketotifen for asthma in children aged 5 to 15 years: a randomized placebo-controlled trial. Ann Allergy Asthma Immunol 85(1):46-52. https://doi.org/ 10.1016/S1081-1206(10)62433-7

Kaji T, Kaga K, Miezi N, Ejiri N, Sakuragawa N (1990) A stimulatory effect of Artemisia leaf extract on the proliferation of cultured endothelial cells. Chem Pharm Bull (Tokyo) 38(2):538-540. https://doi.org/10.1248/cpb.38.538

Kalaiselvi D, Mohankumar A, Shanmugam G, Thiruppathi G, Nivitha S, Sundararaj P (2019) Altitude-related changes in the phytochemical profile of essential oils extracted from Artemisia nilagirica and their nematocidal activity against Meloidogyne incognita. Ind Crops Prod 139:111472. https://doi.org/10.1016/j. indcrop.2019.111472

Kalkanidis M, Klonis N, Tilley L, Deady LW (2002) Novel phenothiazine anti-malarials: synthesis, antimalarial activity, and inhibition of the formation of $\beta$-haematin. Biochem Pharmacol 63(5):833-842. https://doi.org/10.1016/S0006-2952(01)00840-1

Kampf G, Todt D, Pfaender S, Steinmann E (2020) Persistence of coronaviruses on inanimate surfaces and their inactivation with biocidal agents. J Hosp Infect 104(3):246-251. https://doi.org/ 10.1016/j.jhin.2020.01.022

Kangwan N, Park J, Kim E, Hahm KB (2014) Quality of healing of gastric ulcers: natural products beyond acid suppression. World J Gastrointest Pathophysiol 5(1):40-47. https://doi.org/10.4291/ wjgp.v5.i1.40

Karamoddini MK, Emami SA, Ghannad MS, Sani EA, Sahebkar A (2011) Antiviral activities of aerial subsets of Artemisia species against Herpes Simplex virus type 1 (HSV1) in-vitro. Asian Biomed 5(1):63-68. https://doi.org/10.5372/1905-7415.0501.007

Katiyar C, Gupta A, Kanjilal S, Katiyar S (2012) Drug discovery from plant sources: an integrated approach. Ayu 33(1):10-19. https:// doi.org/10.4103/0974-8520.100295

Kavitha KN, Dattatri AN (2013) Experimental evaluation of antidiabetic activity of Swertia Chirata-Aqueous extract. J Public Health Med Res 1(2):71-75
Khan KA (2015) A preclinical antihyperlipidemic evaluation of Artemisia vulgaris root in diet-induced hyperlipidaemic animal model. Int J Pharmacol Res 5(4):110-114. https://doi.org/10. 7439/ijpr

Khan M, Mousa AA, Syamasundar KV, Alkhathlan HZ (2012) Determination of chemical constituents of leafstem essential oils of Artemisia monosperma from central Saudi Arabia. Nat Prod Commun 7(8):1079-1082. https://doi.org/10.1177/1934578X12 00700829

Khan I, Karim N, Ahmad W, Abdelhalim A, Chebib M (2016) GABAA receptor modulation anticonvulsant, anxiolytic, and antidepressant activities of constituents from Artemisia indica Linn. Evid-Based Complement Altern Med. https://doi.org/10.1155/ 2016/1215393

Khezrilu BJ, Heidari R (2014) The evaluation of antioxidant activities and phenolic compounds in leaves and inflorescence of Artemisia dracunculus L. by HPLC. J Med Plants 13(51):41-50

Khosravi H, Rahnema M, Asle-Rousta M (2017) Anxiolytic and antidepressant effects of tarragon (Artemisia dracunculus L.) hydroalcoholic extract in male rats exposed to chronic restraint stress. Nova Biologica Reperta 4:1-8. https://doi.org/10.21859/acadp ub.nbr.4.1.1

Kim J, Choi J, Lee H, Lee MS, Ernst E (2010) Moxibustion for hypertension: a systematic review. BMC Cardiovasc Disord 10:33. https://doi.org/10.1186/1471-2261-10-33

Kim J, Park S, Lim J, Sohn S, Shin J, Park S (2017) Gastroprotective effects of the isopropanol extract of Artemisia princeps and its gastroretentive floating tablets on gastric mucosal injury. Acta Pharm 67:479-494. https://doi.org/10.1515/acph-2017-0037

Kishore N, Dubey NK, Chansouria JPN (2001) Antimycotic activity of the essential of Artemisia nilagirica. Flavour Fragr J 16(1):6163. https://doi.org/10.1002/1099-1026(200101/02)16:1\%3c61:: AID-FFJ946\%3e3.0.CO;2-V

Kodippili K, Ratnasooriya WD, Premakumara S, Udagama PV (2011) An investigation of the antimalarial activity of Artemisia vulgaris leaf extract in a rodent malaria model. Int J Green Pharm. https:// doi.org/10.22377/ijgp.v5i4

Konda VGR, Madhavi E, Ruckmani A, Venkataramana Y (2013) A review on medicinal plants with potential hypolipidemic activity. Int J Pharm Biol Sci 4(4):729-740

Konstat-Korzenny E, Ascencio-Aragon JA, Niezen-Lugo S, VazquezLopez R (2018) Artemisinin and its synthetic derivatives as a possible therapy for cancer. Med Sci 6(1):19. https://doi.org/10. 3390/medsci6010019

Kooy F, Sullivan SE (2013) The complexity of medicinal plants: the traditional Artemisia annua formulation, current status and future perspectives. J Ethnopharmacol 150(1):1-13. https://doi.org/10. 1016/j.jep.2013.08.021

Kordali S, Kotan R, Mavi A, Cakir A, Ala A, Yildirim A (2005) Determination of the chemical composition and antioxidant activity of the essential oil of Artemisia dracunculus and of the antifungal and antibacterial activities of Turkish Artemisa absinthium, Artemisia dracunculus, Artemisia santonicum, and Artemisia spicigera essential oils. J Agric Food Chem 53(24):9452-9458. https://doi.org/10.1021/jf0516538

Koul B, Taak P, Kumar A, Khatri T, Sanyal I (2017) The Artemisia genus: a review on traditional uses, phytochemical constituents, pharmacological properties and germplasm conservation. J Glycomics Lipidomics 7:1. https://doi.org/10.4172/2153-0637. 1000142

Kruth HS (2001) Lipoprotein cholesterol and atherosclerosis. Curr Mol Med 1(6):633-653. https://doi.org/10.2174/1566524013363212

Kuipers EJ (2015) Pernicious anaemia, atrophic gastritis, and the risk of cancer. Clin Gastroenterol Hepatol 13(13):2290-2292. https:// doi.org/10.1016/j.cgh.2015.07.013 
Kumar S, Madaan R, Bansal G, Jamwal A, Sharma A (2012) Plants and plants products with potential anticonvulsant activity-a review. Pharmacogn Commun 2(1):3-99. https://doi.org/10. 5530/pc.2012.suppl1.2

Kumari P, Singh BK, Joshi GC, Tewari LM (2009) Veterinary ethnomedicinal plants in Uttarakhand Himalayan Region, India. Ethnobot Leafl 13:1312-1327. https://opensiuc.lib.siu.edu/ebl/ vol2009/iss 10/11

Lachenmeier DW (2010) Wormwood (Artemisia absinthium L.) - a curious plant with both neurotoxic and neuroprotective properties? J Ethnopharmacol 131:224-227. https://doi.org/10. 1016/j.jep.2010.05.062

Lachenmeier DW, Uebelacker M (2010) Risk assessment of thujone in foods and medicines containing sage and wormwood-evidence for a need of regulatory changes? Regul Toxicol Pharmacol 58(3):437-443. https://doi.org/10.1016/j.yrtph. 2010.08.012

Le TB, Beaufay C, Bonneau N (2018) Anti-protozoal activity of essential oils and their constituents against Leishmania, Plasmodium, and Trypanosoma. Phytochimie 18(1):1-33. http:// hdl.handle.net/2078.1/199166

Li S, Chen C, Zhang H, Guo H, Wang H, Wang L, Zhang X, Hua S, Yu J, Xiao P, Li R, Tan X (2005) Identification of natural compounds with antiviral activities against SARS-associated coronavirus. Antivir Res 67:18-23. https://doi.org/10.1016/j. antiviral.2005.02.007

Lian G, Li F, Yin Y, Chen L, Yang J (2018) Herbal extract of Artemisia vulgaris (mugwort) induces antitumor effects in HCT-15 human colon cancer cells via autophagy induction, cell migration suppression and loss of mitochondrial membrane potential. J Buon 23(1):73-78

Lin L, Hsu W, Lin C (2014) Antiviral natural products and herbal medicines. J Tradit Complement Med 4(1):24-35. https://doi. org/10.4103/2225-4110.124335

Longo M, Zanoncelli S, Torre PD, Riflettuto M, Cocco F, Pesenti M, Giusti A, Colombo P, Brughera M, Mazue G, Navaratman V, Gomes M, Olliaro P (2006) In-vivo and in-vitro investigations of the effects of the antimalarial drug dihydroartemisinin (DHA) on rat embryos. Reprod Toxicol 22(4):797-810. https:// doi.org/10.1016/j.reprotox.2006.08.001

Loo CSN, Lam NSK, Yu D, Su X (2017) Artemisinin and its derivatives in treating protozoan infections beyond malaria. Pharmacol Res 117:192-217. https://doi.org/10.1016/j.phrs.2016. 11.012

Lopez CP, Sumalapao DEP, Villarante NR (2017) Hepatoprotective activity of aqueous ethanolic Bixa orellana L. leaf extracts against carbon tetrachloride-induced hepatotoxicity. Natl J Physiol Pharm Pharmacol 7(9):972-976. https://doi.org/10.5455/ njppp.2017.7.0412011052017

Loscher W, Schmidt D (2006) New horizons in the development of antiepileptic drugs: innovative strategies. Epilepsy Res 63(3):183-271. https://doi.org/10.1016/j.eplepsyres.2006.03.014

Luo H, Tang QL, Shang YX, Liang SB, Yang M, Robinson N, Liu JP (2020) Can Chinese medicine be used for prevention of corona virus disease 2019 (COVID-19)? a review of historical classics, research evidence and current prevention programs. Chin J Integr Med. https://doi.org/10.1007/s11655-020-3192-6

Lutgen P (2019) Artemisia afra and hypertension. Pharm Pharmacol Int J 7(6):297-300. https://doi.org/10.15406/ppij.2019.07.00267

Mahmoudi M, Ebrahimzadeh MA, Ansaroudi F (2009) Antidepressant and antioxidant activities of Artemisia absinthium L. at flowering stage. Afr J Biotechnol 8(24):7170-7175. https://doi.org/10. 5897/AJB09.753

Malhi H, Gores GJ (2008) Cellular and molecular mechanisms of liver injury. Gastroenterology 134(6):1641-1654. https://doi.org/10. 1053/j.gastro.2008.03.002
Mali RG, Dhake AS (2011) A review on herbal antiasthmatics. Orient Pharm Exp Med 11(2):77-90. https://doi.org/10.1007/ s13596-011-0019-1

Malik JA (2017) Ethnopharmacological properties of Artemisia genus used by the traditional healers of Kashmir. Indo Am J Pharm Sci 4(8):2738-2743

Mamatova AS, Korona-Glowniak I, Skalicka-Wozniak K, Jozefczyk A, Wojtanowski KK, Baj T, Sakipova ZB, Malm A (2019) Phytochemical composition of wormwood (Artemisia gmelinii) extracts in respect of their antimicrobial activity. Complement Altern Med 19(1):288. https://doi.org/10.1186/s12906-019-2719-x

Mankani KL, Krishna V, Manjunatha BK, Vidya SM, Singh SDJ (2005) Evaluation of hepatoprotective activity of stem bark of Pterocarpus marsupium Roxb. Indian J Pharmacol 37(3):165168. https://doi.org/10.4103/0253-7613.16213

Marcus EA, Vagin O, Tokhtaeva E, Sachs G, Scott DR (2013) Helicobacter pylori impedes acid-induced tightening of gastric epithelial junctions. Am J Physiol Gastrointest Liver Physiol 305:G731-G739. https://doi.org/10.1152/ajpgi.00209.2013

Matvieieva N, Drobot K, Duplij V (2019) Flavonoid content and antioxidant activity of Artemisia vulgaris L. "hairy roots. Prep Biochem Biotechnol 49(1):82-87. https://doi.org/10.1080/10826068. 2018.1536994

Medhi B, Patyar S, Rao RS, Byrav P, Prakash A (2009) Pharmacokinetic and toxicological profile of artemisinin compounds: an update. Pharmacology 84(6):323-332. https://doi.org/10.1159/ 000252658

Medici TC, Radielovic P, Morley J (1989) Ketotifen in the prophylaxis of extrinsic bronchial asthma. A multicentre controlled double-blind study with a modified-release formulation. Chest 96(6):1252-1257. https://doi.org/10.1378/chest.96.6.1252

Melguizo-Melguizo D, Diaz-de-Cerio E, Quirantes-Pine R, SvarcGajic J, Segura-Carretero A (2014) The potential of Artemisia vulgaris leaves as a source of antioxidant phenolic compounds. J Funct Foods 10:192-200. https://doi.org/10.1016/j.jff.2014. 05.019

Mesa LE, Lutgen P, Velez ID, Segura AM, Robledo SM (2015) Artemisia annиa L., potential source of molecules with pharmacological activity in human diseases. Am J Phytomed Clin Ther 3(5):436-450 (Corpus ID 39568261)

Min Y, Ming-yang G, Yong L, Ming-dong Y, Jiao Y, Tao L, Changhong X (2016) Effect of Artemisia annua extract on treating active rheumatoid arthritis: a randomized controlled trial. Chin J Integr Med 23(7):496-503. https://doi.org/10.1007/ s11655-016-2650-7

Mirjalili MH, Tabatabaei SMF, Hadian J, Nejad-Ebrahimi S, Sonboli A (2007) Phenological variation of the essential oil of Artemisia scoparia Waldst. et. Kit. from Iran. J Essent Oil Res 19(4):326329. https://doi.org/10.1080/10412905.2007.9699294

Mishra T, Srivastava M, Kumar A, Pal M, Tewari SK (2017) Chemical composition and termiticidal activity of Artemisia nilagirica essential oil growing in Southern hilly regions of India. J Essent Oil-Bear Plants 20(1):247-252. https://doi.org/10.1080/09720 60X.2016.1256235

Mittal P, Kaushik D, Kaushik P, Gupta V, Ghaiye P, Krishan P (2011) Therapeutic efficacy of phytochemicals as anti-epileptic-a review. Pharmacologyonline 1:246-271

Mohamed AEH, El-Sayed MA, Hegazy ME (2010) Chemical constituents and biological activities of Artemisia herba-alba. Rec Nat Prod 4(1):1-25. http://www.acgpubs.org/RNP/2010/Volum

Mohanty B, Puri S, Kesavan V (2018) A review on therapeutic potential of Artemisia nilagirica. J Plant Biochem Physiol 6(1):1-5. https://doi.org/10.4172/2329-9029.1000205

Mojarab M, Emami SA, Hassanzadeh-Khayyat M (2009) Antioxidant activity of methanol extracts of different species of Artemisia from Iran. Pharmacologyonline 2:797-807 
Mojarrab M, Lagzianb M, Emamic SA, Asilic J, Tayarani-Najaran Z (2013) In-vitro anti-proliferative and apoptotic activity of different fractions of Artemisia armeniaca. Revista Brasileira de Farmacognosia 23(5):783-788. https://doi.org/10.1590/S0102$695 \times 2013000500010$

Moraes TM, Kushima H, Moleiro FC, Santos RC, Rocha LRM (2009) Effects of limonene and essential oil from Citrus aurantium on gastric mucosa: role of prostaglandins and gastric mucus secretion. Chem Bio Interact 180:499-505. https://doi.org/10.1016/j. cbi.2009.04.006

Moran A, Carron R, Martin ML, Roman LS (1989) Antiasthmatic activity of Artemisia caerulescens subsp. gallica. Planta Med 55(4):351-353. https://doi.org/10.1055/s-2006-962026

Morris D, Khurasany M, Nguyen T, Kim J, Guilford F, Mehta R (2013) Glutathione and infection. Biochim Biophys Acta 1830(5):3329_ 3349. https://doi.org/10.1016/j.bbagen.2012.10.012

Msaada K, Salem N, Bachrouch O, Bousselmi S, Tammar S (2015) Chemical composition and antioxidant and antimicrobial activities of wormwood (Artemisia absinthium L.) essential oils and phenolics. J Chem. https://doi.org/10.1155/2015/804658

Mucciarelli M, Caramiello R, Maffei M (1995) Essential oils from some Artemisia species growing spontaneously in North-West Italy. Flavour Fragr J 10:25-32. https://doi.org/10.1002/ffj.27301 00105

Mueller MS, Karhagomba IB, Hirt HM, Wemakor E (2000) The potential of Artemisia annua L. as a locally produced remedy for malaria in the tropics: agricultural, chemical and clinical aspects. J Ethnopharmacol 73(3):487-493. https://doi.org/10. 1016/s0378-8741(00)00289-0

Mughees M, Wajid S (2019) Artemisia absinthium nanoparticles induce apoptosis in breast cancer cells via inhibiting vesicular trafficking related proteins. https://doi.org/10.1093/annonc/mdz413.032

Murugasan N, Vember S, Damodharanm C (1981) Studies on erythrocyte membrane IV. In-vitro haemolytic activity of Oleet extract. Toxicol Lett 8:33-38. https://doi.org/10.1016/0378-4274(81) 90134-x

Nadeem M, Shinwari ZK, Qaiser M (2013) Screening of folk remedies by genus Artemisia based on ethnomedicinal surveys and traditional knowledge of native communities of Pakistan. Pak J Bot 45(S1):111-117

Naik SK, Mohanty S, Padhi R, Pati R, Sinawane A (2014) Evaluation of antibacterial and cytotoxic activity of Artemisia nilagirica and Murraya koenigii leaf extracts against mycobacteria and macrophages. BMC Complement Altern Med 14:87. https://doi.org/ 10.1186/1472-6882-14-87

Nair S, Varalakshmi KN (2011) Anticancer, cytotoxic potential of Moringa oleifera extracts on HeLa cell line. J Nat Pharm 2(3):138142. https://doi.org/10.4103/2229-5119.86260

Nawab A, Yunus M, Mahdi AA, Gupta S (2011) Evaluation of anticancer properties of medicinal plants from the Indian sub-continent. Mol Cell Pharmacol 3(1):21-29. https://doi.org/10.4255/ MCPHARMACOL.11.04

Negahban M, Moharramipour S, Sefidkon F (2006) Chemical composition and insecticidal activity of Artemisia scoparia essential oil against three coleopteran stored-product insects. J Asia-Pac Entomol 9(4):381-388. https://doi.org/10.1016/S1226-8615(08) 60318-0

Negi AS, Kumar JK, Luqman S, Saikia D, Khanuja SPS (2010) Antitubercular potential of plants: a brief account of some important molecules. Med Res Rev 30(4):603-645. https://doi.org/10.1002/ med.20170

$\mathrm{Ng}$ TB (2004) Antifungal proteins and peptides of leguminous and non-leguminous origins. Peptides 25(7):1215-1222. https://doi. org/10.1016/j.peptides.2004.03.012

Ngadino S, Koerniasari E, Sudjarwo SA (2018) Evaluation of antimycobacterial activity of Curcuma xanthorrhiza ethanolic extract against Mycobacterium tuberculosis $\mathrm{H} 37 \mathrm{Rv}$ in-vitro. Vet World 11(3):368-372. https://doi.org/10.14202/vetworld. 2018.368-372

Nibret E, Wink M (2010) Volatile components of four Ethiopian Artemisia species extracts and their in vitro antitrypanosomal cytotoxic activities. Phytomedicine 17(5):369-374. https://doi.org/ 10.1016/j.phymed.2009.07.016

Nigam M, Atanassova M, Mishra AP, Pezzani R, Devkota HP, Plygun S (2019) Bioactive compounds and health benefits of Artemisia species. Nat Prod Commun. https://doi.org/10.1177/1934578X19 850354

Nikpay A, Soltani M (2018) In-vitro anti-parasitic activities of Pulicaria dysenterica and Lycopus europaeus methanolic extracts against Trichomonas gallinae. J Herbed Pharmacol 7(2):112118. https://doi.org/10.15171/jhp.2018.19

Ninditya VI, Purwati E, Utami AT, Marwaningtyaz AS, Fairuz NK, Widayanti R, Hamid PH (2020) Artemisia vulgaris efficacies against various stages of Aedes aegypti. Vet World 13(7):14231429. https://doi.org/10.14202/vetworld.2020

Nontprasert A, Nosten-Bertrand S, Pukrittayakamee M, Vanijanonta S, Angus BJ, White NJ (1998) Assessment of the neurotoxicity of parenteral artemisinin derivatives in mice. Am J Trop Med Hyg 59(4):519-522. https://doi.org/10.4269/ajtmh.1998.59.519

Nontprasert A, Pukrittayakamee S, Nosten-Bertrand M, Vanijanonta S, White NJ (2000) Studies of the neurotoxicity of oral artemisinin derivatives in mice. Am J Trop Med Hyg 62(3):409-412. https:// doi.org/10.4269/ajtmh.2000.62.409

Noori A, Amjad L, Yazdani F (2014) The effects of Artemisia deserti ethanolic extract on pathology and function of rat kidney. Avicenna J Phytomed 4(6):371-376. https://doi.org/10.22038/AJP. 2014.3259

Novack GD, Stark LG, Peterson SL (1978) Anticonvulsant effects of benzhydryl piperazines on pentylenetetrazol-induced seizures in mice. Neuropharmacology 17(8):659-663. https://doi.org/ 10.1016/0028-3908(78)90164-8

Nsour WM, Lau CBS, Wrong ICK (2000) Review on phytotherapy in epilepsy. Seizure 9(2):96-107. https://doi.org/10.1053/seiz. 1999.0378

Numonov S, Sharopov F, Salimov A, Sukhrobov P (2019) Assessment of artemisinin contents in selected Artemisia species from Tajikistan (Central Asia). Medicines (Basel) 6(1):23. https://doi.org/ 10.3390/medicines6010023

Nussbaum K, Honek J, Cadmus C, Efferth T (2007) Trypanosomatid parasites causing neglected diseases. Curr Med Chem 17(15):1594-1617. https://doi.org/10.2174/092986710790979 953

Obniska J, Kolaczkowski M, Bojarski AJ, Duszynska B (2006) Synthesis, anticonvulsant activity and 5-HT1A, 5-HT2A receptor affinity of new $\mathrm{N}$-[(4-arylpiperazin-1-yl)-alkyl] derivatives of 2-azaspiro [4.4] nonane and [4.5] decane-1,3-dione. Eur J Med Chem 41(7):874-881. https://doi.org/10.1016/j.ejmech.2006.03. 001

Obolskiy D, Pischel I, Feistel B, Glotov N, Heinrich M (2011) Artemisia dracunculus L. (Tarragon): a critical review of its traditional use, chemical composition, pharmacology and safety. J. Agric Food Chem 59(21):11367-11384. https://doi.org/10.1021/jf202 $277 \mathrm{w}$

Ogbole EA, IdyuIsaiah OT, Asalu AF, Builders M, Aguiyi J (2014) Acute toxicity studies of locally cultivated Artemisia annua leaf extract in Rats. World J Pharm Sci 2(12):1864-1870

Oliveira FA, Andrade LN, Sousa EBV, Sousa DP (2014) Anti-Ulcer activity of essential oil constituents. Molecules 19(5):57175747. https://doi.org/10.3390/molecules 19055717

Osorio JCC, Garcia AMG (2019) Antiparasitic phytotherapy perspectives, scope and current development. Infectio 23(2):189-204. https://doi.org/10.22354/in.v23i2.777 
Padalia RC, Verma RS, Chauhan A, Chanotiya CS (2014) Seasonal variation in essential oil composition of Artemisia nilagirica var. septentrionalis from Foot Hills of Western Himalaya. Rec Nat Prod 8(3):81-285

Pal P, Ghosh AK (2018) Antioxidant, Anti-alzheimer and Antiparkinson activity of Artemisia nilagirica leaves with flowering tops. UK J Pharm Biosci 6(2):12-23. https://doi.org/10.20510/ ukjpb/6/i2/173536

Panda S, Rout JR, Pati P, Ranjit M (2018) Antimalarial activity of Artemisia nilagirica against Plasmodium falciparum. J Parasit Dis 42(1):22-27. https://doi.org/10.1007/s12639-017-0956-9

Pandey AK, Singh P (2017) The genus Artemisia: a 2012-2017 literature review on chemical composition, antimicrobial, insecticidal and antioxidant activities of essential oils. Medicines (Basel) 4(3):68. https://doi.org/10.3390/medicines4030068

Paneerselvam C, Murugan K, Kovendan K (2012) Mosquito larvicidal, pupicidal, adulticidal and repellent activity of Artemisia nilagirica (Family, Compositae) against Anopheles stephensi and Ades aegypti. Parasitol Res 111(6):2241-2251. https://doi. org/10.1007/s00436-012-3073-9

Paramakrishnan N, Ahuja J, Suresh J, Khan MN, Sebastian M (2012) Evaluation of acute oral toxicity of aerial parts of Artemisia parviflora Roxb. in Swiss albino mice. Der Pharm Sin 3(1):99-103

Parameswari P, Devika R (2014) Phytochemical screening of bioactive compounds of Artemisia nilagirica (Clarke) pamp. J Chem Pharm Sci 7(4):351-354

Parameswari P, Devika R, Vijyaraghavan P (2019) In-vitro anti-inflammatory and antimicrobial potential of leaf extract from Artemisia nilagirica (Clarke) Pump. Saudi J Biol Sci 26(3):460-463. https://doi.org/10.1016/j.sjbs.2018.09.005

Park SH, Sim YB, Han PL, Lee JK, Suh HW (2010) Antidepressantlike effect of chlorogenic acid isolated from Artemisia capillaris Thunb. Anim Cells Syst 14(4):253-259. https://doi.org/10.1080/ 19768354.2010.528192

Pavithra KS, Annadurai J, Raghunathan R (2018) Phytochemical, antioxidants and a study of bioactive compounds from Artemisia pallens. J Pharmacogn Phytochem 7(4):664-675

Payne D (1987) Spread of chloroquine resistance in Plasmodium falciparum. Parasitol Today 3(8):241-246. https://doi.org/10.1016/ 0169-4758(87)90147-5

Perazzo FF, Lima LM, Maistro EL, Carvalho JE, Rehder VLG, Carvalho JCT (2008) Effect of Artemisia апnиa L. leaves essential oil and ethanol extract on behavioral assays. Revista Brasileira de Farmacognosia 18(1):686. https://doi.org/10.1590/S0102-695X2 008000500008

Pereira CG, Barreira L, Bijttebier S, Pieters L, Marques C (2018) The health-promoting potential of herbal teas tinctures from Artemisia campestris subsp. maritima, from traditional remedies to prospective products. Sci Rep 8:4689. https://doi.org/10.1038/ s41598-018-23038-6

Peters W, Pasvol G (2007) Atlas of tropical medicine and parasitology, 6th edn. Mosby Elsevier, ISBN 9780323043649

Pezzuto JM (1997) Plant-derived anticancer agents. Biochem Pharmacol 53(2):121-133. https://doi.org/10.1016/s0006-2952(96) 00654-5

Pino JA, Rohlado A, Fuentcs V (1999) Composition of the essential oil of Artemisia vulgaris L. herb from Cuba. J Essent Res 11:477478. https://doi.org/10.1080/10412905.1999.9701189

Pohlit AM, Rezende AR, Lopez-Baldin EL, Peporine-Lopes N, derade-Neto VF (2011) Plant extracts, isolated phytochemicals, and plant-derived agents which are lethal to arthropod vectors of human tropical diseases-a review. Planta Med 77(6):618-630. https://doi.org/10.1055/s-0030-1270949

Porrini MP, Fernez NJ, Garrido PM (2011) In-vivo evaluation of antiparasitic activity of plant extracts on Nosema ceranae
(Microsporidia). Apidologie 42:700-707. https://doi.org/10. 1007/s13592-011-0076-y

Pradeep P, Rengaswamy D (2016) Quantitative analysis of bioactive compounds of Artemisia nilagirica (Clarke) Pamp. leaf extracts. Asian J Pharm Clin Res 9(2):183-184. https://doi.org/10.22159/ ajpcr.2016.v9s2.13480

Prakash O, Kumar A, Kumar P, Ajeet A (2013) Anticancer potential of plants and natural products: a review. Am J Pharmacol Sci 1(6):104-115. https://doi.org/10.12691/ajps-1-6-1

Qadir M, Bay JA, Shah WA (2014) GC-MS analysis and antioxidant activity of essential oil of Artemisia amygdalina from Kashmir, India. J Phytopharmacol 3(4):234-237

Qureshi S, Ageel AM, Al-Yahya MA, Tariq M, Mossa JS, Shah AH (1990) Preliminary toxicity studies on ethanol extracts of the aerial parts of Artemisia abyssinica and A. inculta in mice. J Ethnopharmacol 28:157-162. https://doi.org/10.1016/03788741(90)90025-O

Rabe SZT, Mahmoudi M, Ahi A, Emami SA (2011) Antiproliferative effects of extracts from Iranian Artemisia species on cancer cell lines. Pharm Biol 49(9):962-969. https://doi.org/10.3109/13880 209.2011.559251

Raghavendra MP, Sathis S, Anandarao RK (2008) In-vitro antibacterial potential of alkaloids of Samanea samen (Jacq.) merr. against xanthomonas and human pathogenic bacteria. World J Agric Sci 4:101-105

Rahimi S, Zadeh ZT, Torshizi MAK, Omidbaigi R, Rokni H (2011) Effect of the three herbal extracts on growth performance, immune system, blood factors and intestinal selected bacterial population in broiler chickens. J Agric Sci Technol 13(4):527-539

Rahiminejad A, Tappeh KH, Seyyedi S, Mikaili P (2018) The in-vitro effect of hydroalcoholic extract of Artemisia absinthium on the growth of Leishmania major (MRHO/IR/75/ER) in peritoneal macrophages from BALB/c mice. Jundishapur J Microbiol 11(11):e77302. https://doi.org/10.5812/jjm.77302

Rahman MR, Ali M, Sharif M, Tajmim A (2017) A review study on the traditional plants has potential antidepressant property. MOJ Cell Sci Rep 4(5):138-145. https://doi.org/10.15406/mojcsr. 2017.04.00100

Rajendran S, Deepalakshmi PD, Parasakthy K, Devaraj H, Devaraj SN (1996) Effect of tincture of Crataegus on the LDL-receptor activity of hepatic plasma membrane of rats fed an atherogenic diet. Atherosclerosis 123(1-2):235-241. https://doi.org/10.1016/ 0021-9150(96)05813-3235-241

Rana VS, Juyal JP, Blazquez MA, Bodakhe SH (2003) Essential oil composition of Artemisia parviflora aerial parts. Flavour Fragr J 18:342-344. https://doi.org/10.1002/ffj.1239

Rani PN, Moorthi C, Senthamarai R, Kathiresan K (2012) A study to explore the pharmacognostic and phytochemical screening of Artemisia nilagirica leaves found in Nilgiris district of Tamil Nadu. Int J Pharm Pharm Sci 4(4):441-447

Rao MR, Reddy IB, Ramana T (2006) Antimicrobial activity of some Indian medicinal plants. Indian J Microbiol 46:259-262

Rashmi TR, Francis MS, Murali S (2014) Essential oil composition of Artemisia japonica Thunb. from Kerala. J Pharmacogn Phytochem 3(4):160-163. https://www.researchgate.net/publication/ 308208454

Rezaie A, Parker RD, Abdollahi M (2007) Oxidative stress and pathogenesis of inflammatory bowel disease: an epiphenomenon, or the cause? Dig Dis Sci 52(9):2015-2021. https://doi.org/10.1007/ s10620-006-9622-2

Ribeiro A, Pilo-Veloso D, Romanha AJ, Zani CL (1997) Trypanocidal flavonoids from Trixis vauthieri. J Nat Prod 60:836-838. https:// doi.org/10.1021/np970196p

Ribnicky DM, Kuhn P, Poulev A, Logendra S, Zuberi A, Cefalu WT, Raskin I (2009) Improved absorption and bioactivity of active 
compounds from an anti-diabetic extract of Artemisia dracunculus L. Int J Pharm 370(1-2):87-92. https://doi.org/10.1016/j. ijpharm.2008.11.012

Rios JL, Onteniente M, Picazo D, Montesinos MC (2016) Medicinal plants and natural products as potential sources for antiparkinson drugs. Planta Med 82(11/12):942-951. https://doi.org/10. 1055/s-0042-107081

Ryu KJ, Yoou MS, Seo Y, Yoon KW, Kim HM, Jeong HJ (2018) Therapeutic effects of Artemisia scoparia Waldst. et Kitaib in a murine model of atopic dermatitis. Clin Exp Dermatol 43(7):798-805. https://doi.org/10.1111/ced.13565

Sahiner UM, Birben E, Erzurum S, Sackesen C, Kalayci O (2011) Oxidative stress in Asthma. World Allergy Organ J 4(10):151-158. https://doi.org/10.1097/WOX.0b013e318232389e

Sahu N, Meena S, Shukla V, Chaturvedi P, Kumar B, Datta D, Arya KR (2018) Extraction, fractionation and refractionation of Artemisia nilagirica for anticancer activity and HPLC-ESI-QT OF-MS/MS determination. J Ethnopharmacol 213:72-80. https://doi.org/10. 1016/j.jep.2017.10.029

Salehi M, Karimzadeh G, Naghavi MR, Badi HN, Monfared SR (2018) Expression of artemisinin biosynthesis and trichome formation genes in five Artemisia species. Ind Crops Prod 112:130-140. https://doi.org/10.1016/j.indcrop.2017.11.002

Samaha AA, Fawaz M, Salami A (2019) Antihypertensive indigenous lebanese plants: ethnopharmacology and a clinical trial. Biomolecules 9(7):292. https://doi.org/10.3390/biom9070292

Samyal ML, Kumar H, Khokra SL, Parashar B, Sahu RK, Ahmed Z (2011) Evaluation of antidiabetic and antihyperlipidemic effects of Artemisia dracunculus extracts in streptozotocin-induceddiabetic rats. Pharmacologyonline 2:1230-1237. https://www. researchgate.net/publication/235994700

Santilna KS, Mahesh NM, Suresh J (2014) Anticonvulsant activity study of Artemisia nilagirica. Int J Pharmacogn Phytochem Res 6(4):826-830

Seddiek SA, Ali MM, Khater HF (2011) Anthelmintic activity of the white wormwood, Artemisia herba-alba against Heterakis gallinarum infecting turkey poults. J Med Plants Res 5(16):39463957. https://doi.org/10.5897/JMPR2020.7002

Sembiring EN, Elya B, Sauriasari R (2018) Phytochemical screening, total flavonoid and total phenolic content and antioxidant activity of different parts of Caesalpinia bonduc (L.) Roxb. Pharmacogn J 10(1):123-127. https://doi.org/10.5530/pj.2018.1.22

Semenya SS, Maroyi A (2013) Medicinal plants used for the treatment of tuberculosis by Bapedi traditional healers in three districts of the Limpopo Province, South Africa. Afr J Tradit Complement Altern Med 10(2):316-323. https://doi.org/10.4314/ajtcam. v10i2.17

Sen T, Samanta SK (2014) Medicinal plants, human health and biodiversity: a broad review. Adv Biotechnol Appl Biodivers 147:59110. https://doi.org/10.1007/10_2014_273

Sengupta T, Vinayagam J, Nagashayana N, Gowda B, Jaisankar P, Mohanakumar KP (2011) Antiparkinsonian effects of aqueous methanolic extract of Hyoscyamus niger seeds result from its monoamine oxidase inhibitory and hydroxyl radical scavenging potency. Neurochem Res 36(1):177-186. https://doi.org/10.1007/ s11064-010-0289-X

Seo H, Suzuki M, Ohnishi-Kameyama M, Oh M, Kim H, Kim J (2003) Extraction and identification of antioxidant components from Artemisia capillaris herba. Plant Foods Hum Nutr 58(3):1-12. https://doi.org/10.1023/B:QUAL.0000040355.60922.08

Shafaghata A, Noormohammadib Y, Zaifizadeh M (2009) Composition and antibacterial activity of essential oils of Artemisia fragrans Willd. leaves and roots from Iran. Nat Prod Commun 4(2):279282. https://doi.org/10.1177/1934578X0900400223

Shafi PM, Nambiar MKG, Clery RA, Sharma YR (2004) Composition and antifungal activity of the oil of Artemisia nilagirica
(Clarke) Pamp. J Essent Oil Res 16(4):377-379. https://doi. org/10.1080/10412905.2004.9698748

Shaheen F, Khan RA, Soobia A, Khan SA, Saima T (2003) New antimicrobial alkaloids from the roots of Polyalthia longifolia var. pendula. Planta Med 69(4):350-355. https://doi.org/10. 1055/s-2003-38883

Sharifian I, Hashemi SM, Darvishzadeh A (2013) Fumigant toxicity of essential oil of Mugwort (Artemisia vulgaris L.) against three major stored product beetles. Arch Phytopathol Plant Prot 46(4):445-450. https://doi.org/10.1080/03235408.2012. 743389

Sharma J, Gairola S, Gaur RD, Painuli RM, Siddiqi TO (2013) Ethnomedicinal plants used for treating epilepsy by indigenous communities of sub-Himalayan region of Uttarakhand, India. J Ethnopharmacol 150(1):353-370. https://doi.org/10.1016/j.jep. 2013.08.052

Sharma P, Dwivedee BP, Bisht D, Dash AK, Kumar D (2019) The chemical constituents and diverse pharmacological importance of Tinospora cordifolia. Heliyon 5(9):e02437. https://doi.org/10. 1016/j.heliyon.2019.e02437

Shinde S, Sebastian JK, Jain JR, Hanamanthagouda MS, Murthy HN (2016) Efficient in vitro propagation of Artemisia nilagirica var. nilagirica (Indian wormwood) and assessment of genetic fidelity of micropropagated plants. Physiol Mol Biol Plants 22(4):595603. https://doi.org/10.1007/s12298-016-0379-6

Shoaib M, Shah I, Ali N, Adhikari A, Tahir MN, Shah SWA (2017) Sesquiterpene lactone! a promising antioxidant, anticancer and moderate antinociceptive agent from Artemisia macrocephala jacquem. BMC Complement Altern Med 17:27. https://doi.org/ 10.1186/s12906-016-1517-y

Sidaoui F, Igueld SB, Yemmen M (2016) Chemical and functional characterization of Tunisian Artemisia absinthium volatiles and non-volatile extracts obtained by supercritical fluid procedure. Int J Pharm Clin Res 8(8):1178-1185

Sidhu MC, Sharma T (2013) A database of antidiabetic plant species of family Asteraceae, Euphorbiaceae, Fabaceae, Lamiaceae and Moraceae. Int J Herb Med 1(2):152-164

Silva TDJA (2004) Mining the essential oils of the Anthemideae. Afr J Biotechnol 3(12):706-720. http://www.academicjournals.org/ AJB

Singh V, Gaur RD, Bohra B (2008) A survey of fodder plants in midaltitude Himalayan rangelands of Uttarakhand, India. J Mt Sci 5:265-278. https://doi.org/10.1007/s11629-008-0170-4

Singh P, Sonker N, Pandey AK (2015) Chemical composition and antioxidant activity of Essential oil of Artemisia nilagirica Linn. from Eastern Uttar Pradesh, India. J Essent Oil-Bear Plants 18(3):734-738. https://doi.org/10.1080/0972060X.2014.960267

Singh A, Hart R, Chra S, Nautiyal MC, Sayok AK (2019) Traditional herbal knowledge among the inhabitants: a case study in Urgam Valley of Chamoli Garhwal, Uttarakhand, India. Evid-Based Complement Altern Med 2:1-21. https://doi.org/10.1155/2019/ 5656925

Skowyra M, Gallego MG, Segovia F, Almajano MP (2014) Antioxidant properties of Artemisia аппиа extracts in model food emulsions. Antioxidants 3(1):116-128. https://doi.org/10.3390/antiox3010 116

Smith MC, Bleck TP (1991) Convulsive disorders: toxicity of anticonvulsants. Clin Neuropharmacol 14(2):97-115. https://doi.org/10. 1097/00002826-199104000-00001

Snow RW, Trappe JF, Marsh K (2001) The past, present and future of childhood malaria mortality in Africa. Trends Parasitol 17:593597. https://doi.org/10.1016/S1471-4922(01)02031-1

Snow RW, Guerra CA, Noor AM, Myint HY, Hay SI (2005) The global distribution of clinical episodes of Plasmodium falciparum malaria. Nature 434(7030):214-217. https://doi.org/10.1038/ nature 03342 
Solowey E, Lichtenstein M, Sallon S, Paavilainen H, Solowey E, Lorberboum-Galsk H (2014) Evaluating medicinal plants for anticancer activity. Sci World J. https://doi.org/10.1155/2014/721402

Son DJ, Lee GR, Oh S, Lee SE, Choi WS (2015) Gastroprotective efficacy and safety evaluation of scoparone derivatives on experimentally induced gastric lesions in rodents. Nutrients 7(3):19451964. https://doi.org/10.3390/nu7031945

Sonker N, Pandey AK, Singh P (2015) Efficiency of Artemisia nilagirica (Clarke) Pamp. essential oil as a mycotoxicant against postharvest mycobiota of table grapes. J Sci Food Agric 95(9):19321939. https://doi.org/10.1002/jsfa.6901

Soufli I, Toumi R, Rafa H, Touil-Boukoffa C (2016) Overview of cytokines and nitric oxide involvement in immuno-pathogenesis of inflammatory bowel diseases. World J Gastrointest Pharmacol Ther 7(3):353-360. https://doi.org/10.4292/wjgpt.v7.i3.353

Stappen I, Wanner J, Tabanca N, Wedge DE (2014) Chemical composition and biological effects of Artemisia maritima and Artemisia nilagirica essential oils from wild plants of Western Himalaya. Planta Med 80(13):1079-1087. https://doi.org/10.1055/s-00341382957

Stavri M, Mathew KT, Gibson T, Williamson RT, Gibbons S (2004) New constituents of Artemisia monosperma. J Nat Prod 67(5):892-894. https://doi.org/10.1021/np030558v

Storz P (2005) Reactive oxygen species in tumour progression. Front Biosci 10:1881-1896. https://doi.org/10.2741/1667

Su X, Miller LH (2015) The discovery of artemisinin and Nobel Prize in Physiology or Medicine. Sci China Life Sci 58(11):11751179. https://doi.org/10.1007/s11427-015-4948-7

Suberu JO, Gorka AP, Jacobs L, Roepe PD, Sullivan N, Barker GC, Lapkin AA (2013) Anti-plasmodial polyvalent interactions in Artemisia аппиа L. aqueous extract-possible synergistic and resistance mechanisms. Plos One 8(11):e80790. https://doi.org/ 10.1371/journal.pone. 0080790

Sun WC, Han JX, Yang WY, Deng DA, Yue XF (1992) Antitumor activities of 4 derivatives of artemisic acid artemisinin B in-vitro. Acta Pharm Sin 13:541-543

Suresh J, Vasavi RA, Dhanya R, Ihsanullah M, Mohd NK (2010) Antimicrobial Activity of Artemisia abrotanum and Artemisia pallens. Int J Pharmacogn Phytochem Res 3(2):18-21

Suresh J, Mahesh NM, Ahuja J, Santilna KS (2011) Review on Artemisia nilagirica (Clarke) Pamp. J Biol Act Prod Nat 1(2):97-104. https://doi.org/10.1080/22311866.2011.10719075

Suresh J, Ahuja J, Paramakrishnan N (2012) Pharmacognostical investigation of Artemisia parviflora Roxb. Asian Pac J Trop Biomed 2(2):S532-S535. https://doi.org/10.1016/S2221-1691(12) 60267-6

Sussman L (1980) Herbal medicine on Mauritius. J Ethnopharmacol 2(3):259-278. https://doi.org/10.1016/S0378-8741(80)81005-1

Szerlauth A, Murath S, Viski S, Szilagyi I (2019) Radical scavenging activity of plant extracts from improved processing. Heliyon 5(11):e02763. https://doi.org/10.1016/j.heliyon.2019.e02763

Tacke F, Luedde T, Trautwein C (2009) Inflammatory pathways in liver homeostasis and liver injury. Clin Rev Allergy Immunol 36(1):4-12. https://doi.org/10.1007/s12016-008-8091-0

Taherkhani M (2015) Chemical constituents and in-vitro anticancer, cytotoxic, mutagenic and antimutagenic activities of Artemisia diffusa. Pharm Chem J 48(11):727-732. https://doi.org/10.1007/ s11094-015-1182-3

Tahir SM, Bashir SA, Abdulrahman MD, Abdullahi AY (2015) Effect of varying concentrations of auxin $(2,4-\mathrm{D})$ on in-vitro callus initiation using leaf of Artemisia аппиа (L). Sci World J 10(1):17-19

Tajehmiri A, Issapour F, Moslem MN, Lakeh MT, Kolavani MH (2014) In-vitro antimicrobial activity of Artemisia annua leaf extracts against pathogenic bacteria. Adv Stud Biol 6(3):93-97. https:// doi.org/10.12988/asb.2014.4525
Tambo E, Khater EIM, Chen J, Bergquist R, Zhou X (2015) Nobel prize for the artemisinin and ivermectin discoveries: a great boost towards elimination of the global infectious diseases of poverty. Infect Dis Poverty 4:58. https://doi.org/10.1186/ s40249-015-0091-8

Tareen RB, Bibi T, Khan MA, Ahmad M, Zafar M (2010) Indigenous knowledge of folk medicine by the women of Kalat and Khuzdar regions of Balochistan, Pakistan. Pak J Bot 42(3):1465-1485. http://www.pakbs.org/pjbot/PDFs/42(3)

Teixeira D (2004) Mining the essential oils of the Anthemideae. Afr J Biotechnol 3(12):706-720

Temraz A, El-tantawy WH (2008) Characterization of antioxidant activity of extract from Artemisia vulgaris. Pak J Pharm Sci 21(4):321-326

Tewari K, Tewari G, Pande C, Kunwar G (2015) Volatile constituents of Artemisia parviflora Buch.-Ham ex Roxb. from Kumaun Himalayan Region, India. J Essent Oil-Bear Plants 18(1):95-198. https://doi.org/10.1080/0972060X.2014.958567

Thao NTP, Thuy NT, Hoi TM, Muselli THTA, Bighelli A, Castola V, Casanova J (2004) Artemisia vulgaris L. from Vietnam: chemical variability and composition of the oil along the vegetative life of the plant. J Essent Oil Res 16(4):358-361. https://doi.org/10. 1080/10412905.2004.9698742

Tian T, Wang Z, Zhang J (2017) Pathomechanisms of oxidative stress in inflammatory bowel disease and potential antioxidant therapies. Oxid Med Cell Longev. https://doi.org/10.1155/2017/45351 94

Tigno XT, Guzman FD, Flora AMTV (2000) Phytochemical analysis and hemodynamic actions of Artemisia vulgaris L. Clin Hemorheol Microcirc 23(2-4):167-175

Torres YR, Berlinck RGS, Nascimento GGF, Fortier SC, Pessoa C (2002) Antibacterial activity against resistant bacteria and cytotoxicity of four alkaloid toxins isolated from the marine sponge Arenosclera brasiliensis. Toxicon 40:885-891. https://doi.org/ 10.1016/S0041-0101(01)00286-0

Uniyal GC, Singh AK, Shah NC, Naqvi AA (1985) Volatile constituents of Artemisia nilagirica. Planta Med 51(5):457-458. https:// doi.org/10.1055/s-2007-969551

Upur H, Amat N, Blazekovic B, Talip A (2009) Protective effect of Cichorium glandulosum root extract on carbon tetrachlorideinduced and galactosamine-induced hepatotoxicity in mice. Food Chem Toxicol 47(8):2022-2030. https://doi.org/10.1016/j.fct. 2009.05.022

Verma PR, Subburaju T, Balakrishnan N (2006) Larvicidal activity of Artemisia nilagirica (Clarke) Pamp. and Ocimum sanctum L. a preliminary study. J Nat Rem 6(2):157-161. https://doi.org/10. 18311/jnr/2006/460

Wallaart TE, Pras N, Quax WJ (1999) Isolation and identification of dihydroartemisinic acid hydroperoxide from Artemisia апnиа: a novel biosynthetic precursor of Artemisinin. J Nat Prod 62(8):1160-1162. https://doi.org/10.1021/np9900122

Walter HL, Memory PFEL (2003) Medical botany, plants affecting human health, 2nd edn. Wiley, New York, p 345. ISBN, 978-0-471-62882-8

Wang J, Zhu F, Zhou XM, Niu CY, Lei CL (2006) Repellent and fumigant activity of essential oil from Artemisia vulgaris to Tribolium castaneum (Herbst) (Coleoptera, Tenebrionidae). J Stored Prod Res 42(3):339-347. https://doi.org/10.1016/j.jspr.2005.06.001

Wang ZQ, Ribnicky D, Zhang XH, Zuberi A, Raskin I, Yu Y, Cefalu WT (2011) An extract of Artemisia dracunculus L. enhances insulin receptor signaling and modulates gene expression in skeletal muscle in KK-A(y) mice. J Nutr Biochem 22(1):71-78. https://doi.org/10.1016/j.jnutbio.2009.11.015

Wang J, Lin L, Li B, Zhang F, Liu N (2019) Dietary Artemisia vulgaris meal improved growth performance, gut microbes, and immunity 
of growing Rex rabbits. Czeh J Anim Sci 64(4):174-179. https:// doi.org/10.17221/162/2018-CJAS

Weathers PJ, Towler MJ (2014) Changes in key constituents of clonally propagated Artemisia аппиа L. during the preparation of compressed leaf tablets for possible therapeutic use. Ind Crops Prod 62:173-178. https://doi.org/10.1016/j.indcrop.2014.08.033

Weathers PJ, Arsenault PR, Covello PS, McMickle A, Teoh KH, Reed DW (2011) Artemisinin production in Artemisia annua: studies in planta and results of a novel delivery method for treating malaria and other neglected diseases. Phytochem Rev 10(2):173183. https://doi.org/10.1007/s11101-010-9166-0

Weathers PJ, Elfawal MA, Towler MJ, Acquaah-Mensah GK, Rich SM (2014) Pharmacokinetics of artemisinin delivered by oral consumption of Artemisia annua dried leaves in health vs. Plasmodium chabaudi-infected mice. J Ethnopharmacol 153(3):732736. https://doi.org/10.1016/j.jep.2014.03.037

Weber LW, Boll M, Stampfl A (2003) Hepatotoxicity and mechanism of action of haloalkanes: carbon tetrachloride as a toxicological model. Crit Rev Toxicol 33(2):105-136. https://doi.org/10.1080/ 713611034

White TEK, Bushdid PB, Ritter S, Laffan SB, Clark RL (2006) Artesunate-induced depletion of embryonic erythroblasts precedes embryolethality and teratogenicity in-vivo. Birth Defects Res B 77(5):413-429. https://doi.org/10.1002/bdrb.20092

WHO technical document of the use of non-pharmaceutical forms of Artemisia (2019) Malaria Policy Advisory Committee Meeting 2-4 October 2019, Geneva, Switzerland Background document for Session 3. https://www.who.int/malaria/mpac/mpac-octob er2019-session3-non-pharmaceutical-use-artemisia.pdf

Wink M (2012) Medicinal plants: a source of anti-parasitic secondary metabolites. Molecules 17(11):12771-12791. https://doi.org/10. 3390/molecules 171112771

Wolin KY, Carson K, Colditz GA (2010) Obesity and cancer. Oncologist 15(6):556-565. https://doi.org/10.1634/theoncologist. 2009-0285

Wong Ting Fook WTH (1980) The medicinal plants of Mauritius. ENDA in Dakar

Wongsrichanalai C, Nguyen TD, Trieu NT, Wimonwattrawatee T, Sookto P, Heppner DG (1997) In-vitro susceptibility of Plasmodium falciparum isolates in Vietnam to artemisinin derivatives and other antimalarials. Acta Trop 63(2-3):151-158. https://doi. org/10.1016/S0001-706X(96)00618-3

Woo TS, Yoon SY, Pena C, Choi JY (2011) Anticonvulsant effect of Artemisia capillaris Herba in mice. Biomol Ther 19(3):342-347. https://doi.org/10.4062/biomolther.2011.19.3.342

Wright CW (2002) Artemisia, medicinal and aromatic plants-industrial profiles. Taylor Francis, New York. ISBN 978-0-415-27212-4

Xie G, Schepetkin IA, Siemsen DW, Kirprotina LN, Wiley JA, Quinn MT (2008) Fractionation and characterization of biologicallyactive polysaccharides from Artemisia tripartita. Phytochemistry 69(6):1359-1371. https://doi.org/10.1016/j.phytochem.2008.01. 009

Yamahara J, Kobayashi G (1989) Vascular dilatory action of Artemisia capillaris bud extracts and their active constituent. J Ethnopharmacol 26(2):129-136. https://doi.org/10.1016/0378-8741(89) 90060-3

Yang Y, Islam MS, Wang J, Li Y, Chen X (2020) Traditional Chinese medicine in the treatment of patients infected with 2019-new coronavirus (SARS-CoV-2): a review and perspective. Int J Biol Sci 16(10):1708-1717. https://doi.org/10.7150/ijbs.45538

Yeo D, Hwang SJ, Kim WJ (2018) The aqueous extract from Artemisia capillaris inhibits acute gastric mucosal injury by inhibition of
ROS and NF-kB. Biomed Pharmacother 99:681-687. https://doi. org/10.1016/j.biopha.2018.01.118

Yokozawa T, Ishida A, Cho EJ, Nakagawa T (2003) The effects of Coptidis rhizoma extract on a hypercholesterolemic animal model. Phytomedicine 10(1):17-22. https://doi.org/10.1078/0944711033 21648610

Yoshikawa M, Shimada H, Matsuda H, Yamahara J, Murakami N (1996) Bioactive constituents of Chinese natural medicines. I. New sesquiterpenes ketone with vasorelaxant effect from Chinese Moxa, the processed leaves of Artemisia argyi Levl. et VANT.: Moxartenone and Moxartenolide. Chem Pharm Bull (Tokyo) 44(9):1656-1662. https://doi.org/10.1248/cpb.44.1656

Youssefi MR, Abuhosseini TM, Sadeghi HG, Kouhi MK (2011) Antiparasitic efficacy of worm wood (Artemisia absinthium) alcoholic extract on Syphacia obvolata. Iran J Vet Med 6(1):4750. https://doi.org/10.22059/IJVM.2012.24625

Yuan H, Lu X, Ma Q, Li D, Xu G, Piao G (2016) Flavonoids from Artemisia sacrorum Ledeb. and their cytotoxic activities against human cancer cell lines. Exp Ther Med 12(3):1873-1878. https:// doi.org/10.3892/etm.2016.3556

Zahi D, Supaibulwatana K, Zhong J (2010) Inhibition of tumour cell proliferation and induction of apoptosis in human lung carcinoma 95-D cells by a new sesquiterpene from hairy root cultures of Artemisia annua. Phytomedicine 17(11):856-861. https://doi. org/10.1016/j.phymed.2010.02.008

Zapata-Colindres JC, Zepeda-Gomez S, Montano-Loza A, VazquezBallesteros E (2006) The association of Helicobacter pylori infection and nonsteroidal anti-inflammatory drugs in peptic ulcer disease. Can J Gastroenterol 20(4):277-280. https://doi. org/10.1155/2006/175217

Zarezade V, Moludi J, Mostafazadeh M, Mohammadi M (2018) Antioxidant and hepatoprotective effects of Artemisia dracunculus against $\mathrm{CCl}_{4}$-induced hepatotoxicity in rats. Avicenna J Phytomed 8(1):51-62. https://doi.org/10.22038/AJP.2017.19137. 1738

Zeb S, Ali A, Zaman W, Zeb S, Ali S, Ullah F, Shakoor A (2018) Pharmacology, taxonomy and phytochemistry of the genus Artemisia specifically from Pakistan: a comprehensive review. Pharm Biomed Res 4(4):1-10. https://doi.org/10.18502/pbr.v4i4.543

Zhang Y, Xu G, Zhang S, Wang D, Prabha PS, Zuo Z (2018) Antitumor research on artemisinin and its bioactive derivatives. Nat Prod Bioprospect 8(11):303-319. https://doi.org/10.1007/ s13659-018-0162-1

Zhao B, Litscher G, Li J, Wang L, Cui Y, Huang C, Liu P (2011) Effects of Moxa (Artemisia vulgaris) smoke inhalation on heart rate and its variability. Chin Med 2(2):53-57. https://doi.org/10. $4236 / \mathrm{cm} .2011 .22010$

Zhou X, Li C, Chang D, Bensoussan A (2018) Current status and major challenges to the safety and efficacy presented by Chinese herbal medicine. Medicines (Basel) 6(1):14. https://doi.org/10.3390/ medicines6010014

Zime-Diawara H, Gannon H, Gbaguidi F, Yeomoa A, Bero J, Jansen O, Evrard B, Moudachirou M, Frederich M, Quetin-Leclercq J (2015) The antimalarial action of aqueous and hydroalcoholic extracts of Artemisia annua L. cultivated in Benin: in-vitro and in-vivo studies. J Chem Pharm Res 7(8):817-823

Publisher's Note Springer Nature remains neutral with regard to jurisdictional claims in published maps and institutional affiliations. 